\title{
Habitat preferences of coral-associated wentletrap snails (Gastropoda: Epitoniidae)
}

\author{
Adriaan Gittenberger ${ }^{1,2}$, Bert W. Hoeksema ${ }^{1,3}$ \\ ${ }^{1}$ Department of Marine Zoology, Naturalis Biodiversity Center, PO Box 9517, 2300 RA Leiden, The Netherlands \\ ${ }^{2}$ Institute for Environmental Sciences and Institute for Biology, Leiden University, PO Box 9516, 2300 RA Leiden, \\ The Netherlands \\ ${ }^{3}$ E-mail: bert.hoeksema@naturalis.nl
}

Key words: coral-mollusc associations, Fungiidae, Indo-Pacific, parasitic snails, Scleractinia

\begin{abstract}
Examination of about 60,000 scleractinian corals of the families Dendrophylliidae, Euphylliidae and Fungiidae for the presence of associated wentletrap snails (Gastropoda: Epitoniidae) revealed various ectoparasitic life history strategies. Twenty Indo-Pacific wentletrap species were found, which were either host-specific or generalist. Most species were associated with mushroom corals, especially free-living species belonging to the Fungiidae. Snails showed different preferences with regard to their position relative to mushroom corals, the host's size and its substrate. No preferences for depth were found. Infestation rates of mushroom corals in multi-species assemblages were negatively correlated with coral densities, which indicates that epitoniid veliger larvae may actively look for preferential hosts. Indirect proof was found that burrowing shrimps remove any epitoniid that is on or underneath the mushroom coral under which they have their burrow. Fishes like wrasses and damselfishes were seen to eat the snails the moment their host corals were overturned, which suggests that the host corals may provide the snails with protection against predators.
\end{abstract}

\section{Contents}

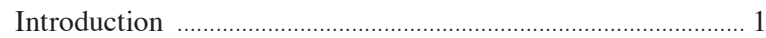

Material and methods .............................................................. 3

Fieldwork localities and general methods .......................... 3

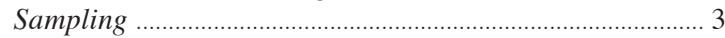

Transect studies ................................................................... 3

Measurement of coral sizes ..................................................... 8

Overturned host corals .................................................... 10

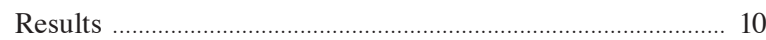

Abundance of infestations ................................................... 10

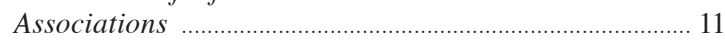

Coral densities and infestation rates .................................. 11

Depth ranges ........................................................................... 11

Substrates and attachment .................................................. 11

Coral sizes .......................................................................... 13

Overturned host corals ............................................................ 14

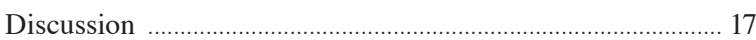

The trophic role of coral-associated epitoniids ............... 17
Coral densities and depth ranges ........................................ 18

Substrates ........................................................................ 19

Coral sizes and risk of host coral turnover ....................... 19

Conclusions and recommendations ......................................... 20

Acknowledgements ................................................................. 21

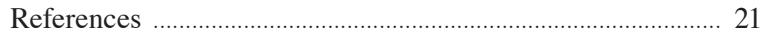

\section{Introduction}

In light of the degradation of coral reefs and the potential for coral species extinctions (Carpenter et al., 2008), understanding the biodiversity and ecological complexity of reef communities and their species interdependences is essential (Castro, 1988; Stella et al., 2010, 2011; Hoeksema et al., 2012a). In the present study corals of the scleractinian families Dendrophylliidae, Euphylliidae, and Fungiidae with their associated wentletraps (Gastropoda: Epitoniidae) are used to study such interrelationships.

Epitoniids are generally known to live in association with anthozoans (Cnidaria), such as species of Actiniaria (Robertson, 1963, 1966, 1983; Perron, 1978; Schimek, 1986; den Hartog, 1987; Kokshoorn et al., 2007; Hoeksema and Crowther, 2011), Zoantharia (Zahn, 1980; Robertson, 1981) or Scleractinia (Gittenberger and Gittenberger, 2005). Morphological and molecular studies have shown that a large, partly cryptic, adaptive radiation occurred among these epitoniids (Gittenberger et al., 2000; Gittenberger, 2003; Gittenberger and Gittenberger, 2005; Kokshoorn et al., 2007). Their geographical distribution ranges track those of their hosts, with the highest numbers in the Indo-West Pacific, especially in the Coral Triangle (Gittenberger and Gittenberger, 2005).

Although the genetic integrity of epitoniids can be demonstrated by molecular data (Gittenberger et al., 
2006; Churchill et al., 2011), shell characters are only partially diagnostic in identifications at species level. In general, life habit and characters of the operculum, the jaw, the radula and the spawn, characterize these conchologically cryptic species much better (Gittenberger and Gittenberger, 2005). These recent findings contradict the hypothesis of Bouchet and Warén (1986: 469) stating that little morphological variation among epitoniids may reflect a low degree of specialization. A fundamental condition for the identification of coralassociated molluscs consists therefore of a good knowledge of the available host coral species (Gittenberger et al., 2000; Kleemann and Hoeksema, 2002; Gittenberger and Gittenberger, 2005, 2011; Hoeksema et al., 2012a).

The snails may use their anthozoan hosts as food source, as protection against predators, or shelter from turbulence. Due to their hidden position, observations of actual feeding epitoniids are scarce (Perron, 1978; den Hartog, 1987; Gofas et al., 2011), but nematocysts in epitoniid gut contents indicate a predatory or parasitic behaviour (Perron, 1978). Apparently, the snails are unaffected by the venom in these nematocysts. Hence, epitoniids are either considered highly specialized micropredators (Robertson, 1970; Hadfield, 1976) or ectoparasites (Gittenberger, 2003; Gittenberger and Gittenberger, 2005). In the present study, they are considered parasites because they live a long period of their life history on a single host without killing it (see Castro, 1988).

Most coral-associated wentletraps are found with mushroom corals (Fungiidae), which are the main focus of this study. The Fungiidae consist of over 50 species exclusively in the Indo-Pacific (Hoeksema, 1989, 1993a, 1993b, 2009, 2012b; Hoeksema and Dai, 1991; Gittenberger et al., 2011; Benzoni et al., 2012). These corals have a high survival rate during bleaching events (Hoeksema, 1991a; Hoeksema and Matthews, 2011; Hoeksema et al., 2012b), which is also important for the survival of their associated fauna (Hoeksema et al., 2013). Most mushroom corals are free-living in adult phase and can easily be picked up and checked for parasites. Depending on shape, size and weight (Hoeksema, 1988, 1991b), such corals may tumble downward along slopes, be pushed by bottomdwelling animals, currents and waves, and they may even move themselves (Hubbard, 1972; Jokiel and Cowdin, 1976; Yamashiro and Nishihira, 1995; Plusquellec et al., 1999; Hoeksema and de Voogd, 2012). This mobility may help mushroom corals to
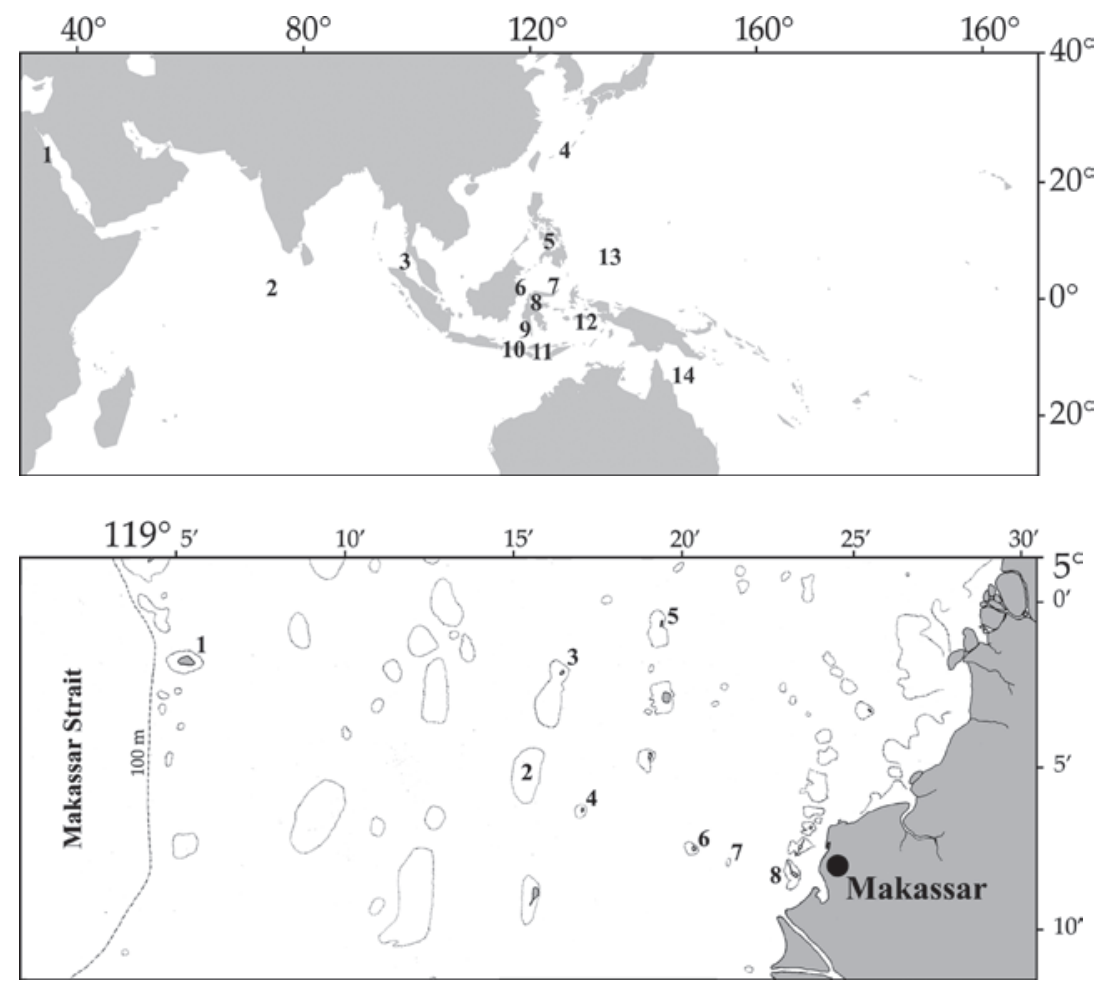

Fig. 1. Research localities in the IndoWest Pacific: 1. Marsha Shagra and Marsa Nakari, c. 350 km S of Hurghada, Egypt; 2. Vilamendhoo Isl., Ari Atoll, Maldives; 3. PhiPhi Isl., Krabi, W Thailand; 4. Okinawa, Rykyu Isl., S Japan; 5. Cebu, Central Philippines; 6. Berau Isl., E Kalimantan, Indonesia; 7. Siladen and Bunaken Isl., N Sulawesi, Indonesia; 8. Togian Isl., Central Sulawesi, Indonesia; 9. Spermonde Archipelago, SW Sulawesi, Indonesia; 10. Bali, Indonesia; 11. Flores, Indonesia; 12. Ambon, Indonesia; 13. Palau; 14 Great Barrier Reef, E Australia.

Fig. 2. Research sites in the southern part of the Spermonde Archipelago, SW Sulawesi, Indonesia, consisting of patch reefs and a barrier reef: 1. Langkai; 2. Kapodasang (shoal); 3. Bone Tambung; 4. Kudingareng Keke; 5. Bone Batang; 6. Samalona; 7. Bone Baku (shoal); 8. LaeLae. 
disperse and prevent lethal burial in sediment (Abe, 1939; Jokiel and Cowdin, 1976; Hoeksema, 1988; Chadwick-Furman and Loya, 1992; Gilmour, 2002; Bongaerts et al., 2012). It may also be functional in avoiding competition for space (Chadwick, 1988; Hoeksema, 2004; Yamashiro and Nishihira, 1995; Hoeksema and de Voogd, 2012). However, movements by the host may also have implications for the survival of the ectoparasitic snails, which will become exposed to predators when the coral accidentally gets turned upside-down. Despite this risk, mushroom corals appear very much to be a preferred host group for epitoniids among Indo-Pacific Scleractinia (none are known from the Atlantic), which justifies their importance in the present study. In short, this study aims to clarify the ecological differentiation of coral-associated epitoniids, particularly regarding their abundance in relation to host coral densities, depth ranges, substrates, sizes, positions and mobility.

\section{Materials and methods}

\section{Fieldwork localities and general methods}

Habitat preferences are described for 20 known species of coral-associated epitoniids, most of which are widespread and associated with only one or a restricted number of host species (Gittenberger and Gittenberger, 2005). Approximately 60,000 mushroom corals were searched in 1997 and from 2000 to 2004 for epitoniids during 800 hours of scuba-diving in Egypt (Red Sea), the Maldives (Indian Ocean), western Thailand (Andaman Sea), western Malaysia (South China Sea), southern Japan, Palau (West Pacific), the Philippines, Indonesia and eastern Australia (Fig. 1). In 1997 and 2001, research took place in periods of three and nine months, respectively, in the Spermonde Archipelago off Makassar, SW Sulawesi, Indonesia (Fig. 2). This area (Hoeksema, 1990, 2012a, c) is located in the centre of maximum marine biodiversity (Hoeksema, 2007). Off Makassar the diversity and densities of potential host coral species were higher than at any of the other study localities (Hoeksema, 2012a). Therefore this archipelago was selected for more detailed field studies. Concentrating on mushroom corals, a special effort was made to search all present species within this family for the presence of peitoniid snails. Mushroom corals species that were formally not yet recognized to belong to the Fungiidae (Benzoni et al., 2007, 2012) were not included in the study. Many of these species live in environments that are usually avoided by divers, e.g. at relatively deep ( $>25$ meter) reef bases or shallow ( $<2$ meter) slopes and flats, or in areas with strong currents, murky water and sandy bottoms (Hoeksema, 2012a).

\section{Sampling}

The snails were collected and conserved in $70 \%$ or 95\% ethanol for morphological or molecular analyses, respectively. Most associations were photographed in detail with a Sea \& Sea SX-1000 SLR camera with a $50 \mathrm{~mm}$ macro lens. A white PVC board and a graphite pencil were used underwater to note observations related to the infestations, i.e. depth, host species, substrate characteristics, and position of the parasite relative to its host. The fungiid specimens were identified twice, independently by both authors, using photographs and/ or specimens. H. Ditlev identified the euphylliids from photographs. The Tubastraea species were not identified to species level. The first author identified the epitoniid species. The position of a parasitic snail was recorded as 'buried in sand', 'on the coral host' (Figs 3-4, 8-9), or 'on the substrate underneath the coral' (Figs 5-7). Regarding the size-dependent mushroom coral mobility (Hoeksema, 1988, 1991b, 2004), an upside-down position of the fungiid host (Figs 5-9, 11, 13-14, 16-17) was recorded versus the regular upright orientation (Figs 10,12). The substrate was characterized as (1) 'flat' for an even bottom of sand, coral or stone, without any crevices (Fig. 12; next to the fungiid coral), as (2) 'burrow' when there was at least one circular burrow (Figs 11, 13-14), possibly made by a crustacean (Fig. 15), or as (3) 'crevices', where crevices occurred but no burrows (Fig. 6).

\section{Transect studies}

In the Spermonde Archipelago (Fig. 2; locality 9 in Fig. 1) mushroom corals were surveyed in belt transects. This was done at seven sites on five coral reefs that vary in mushroom coral fauna, depending on their distance from the coastline (see Hoeksema, 2012a): W Lae-Lae, W Bone Baku, E Samalona, W Samalona, E Kudingareng Keke, W Kudingareng Keke, and NW Langkai (Fig. 2). At each site horizontal transects, marked by a $50 \mathrm{~m}$ long measuring tape, were searched at 3, 6, 9, 12, 15 and $18 \mathrm{~m}$ depth (see Hoeksema, 2012a). This method allows the recording of sufficient abundance data on host and parasites in contrast to the roving diving technique, which only gives incidence data 

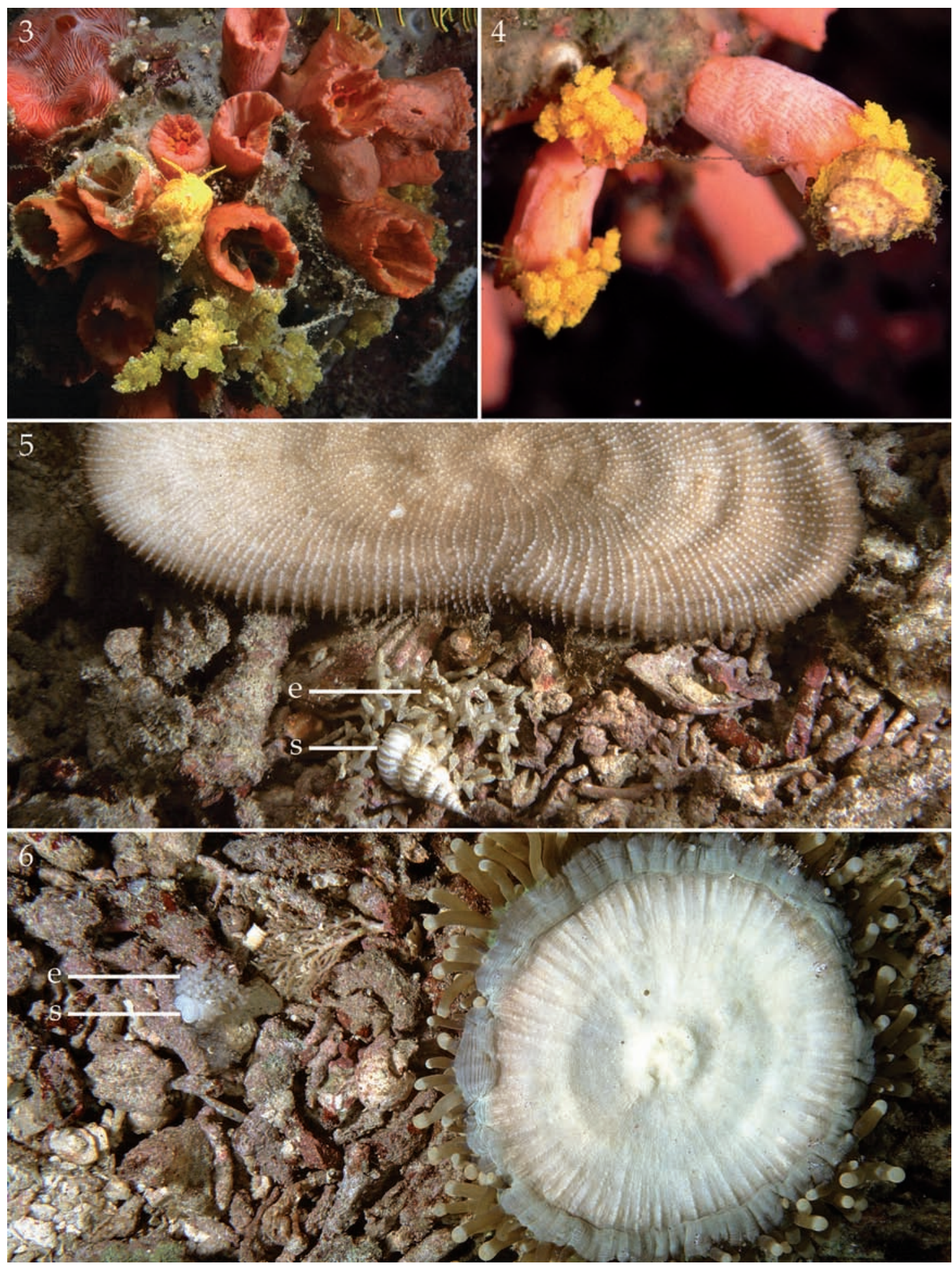

Figs 3-6. Habitats of coral-dwelling Epitoniidae. 3, Epidendrium aureum snail with spawn on substrate next to its dendrophylliid host (Tubastraea sp.); 4, Epidendrium sordidum shell overgrown by hydroids, with spawn on dendrophylliid host (Tubastraea sp.); 5, Surrepifungium costulatum snail with spawn on coarse sand under host (Ctenactis echinata); 6, Epifungium hoeksemai snail with spawn on coarse sand under host (Heliofungia actiniformis). Locations: 3-4, Ari Atoll, Maldives; 5-6, SW Sulawesi, Indonesia. Abbreviations:, $\mathrm{s}=$ snail, $\mathrm{sp}=$ spawn. 

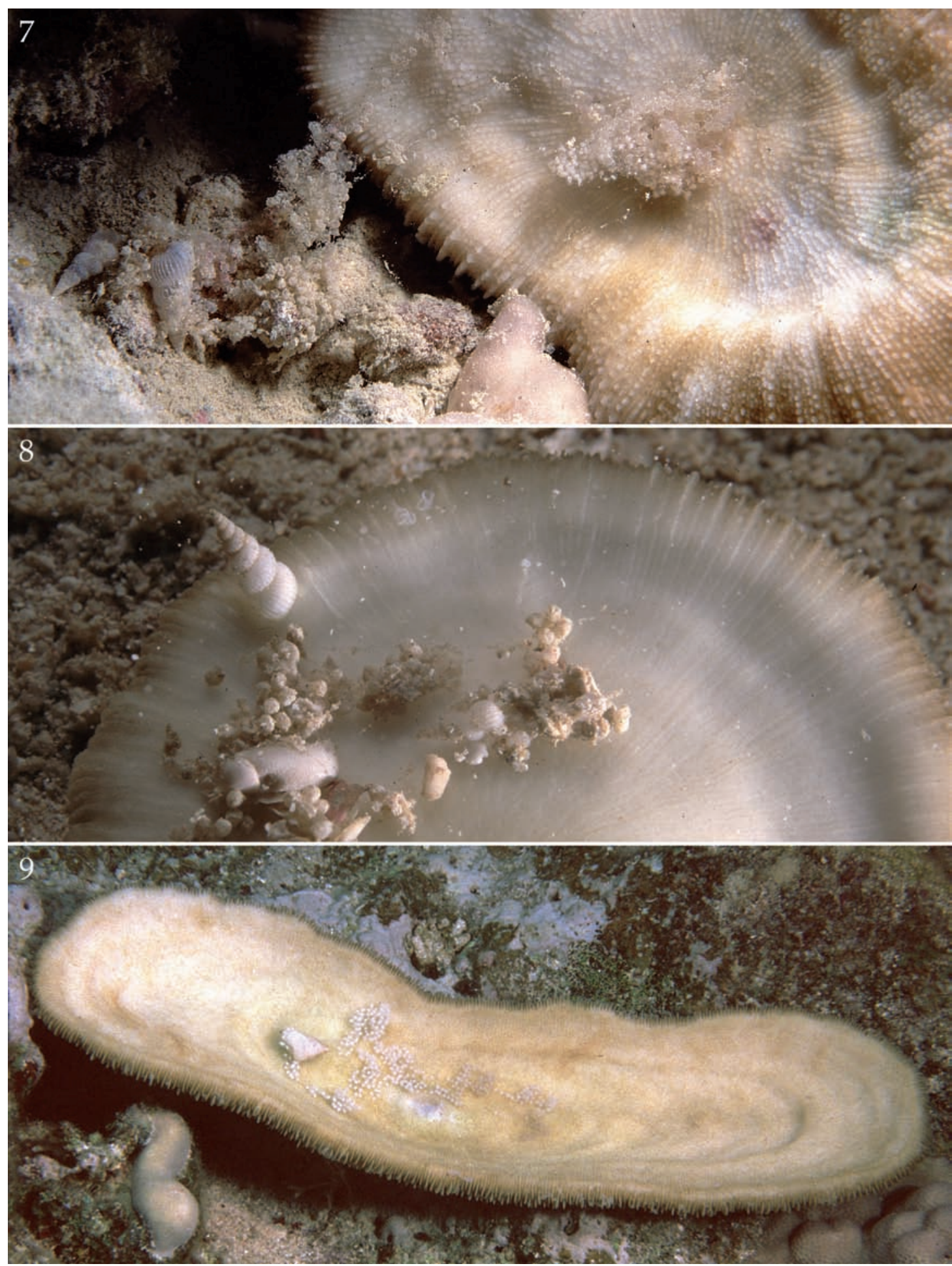

Figs 7-9. Habitats of Epitoniidae (continued); snails with spawns on sandy substrate under fungiid host. 7, Epifungium nielsi under a Pleuractis paumotensis (Ari Atoll, Maldives); 8, Epifungium pseudolochi under a Cycloseris costulata (Marsa Nakari, $350 \mathrm{~km}$ S of Hurghada, Egypt); 9, Epifungium twilae under Herpolitha limax (SW Sulawesi, Indonesia). 

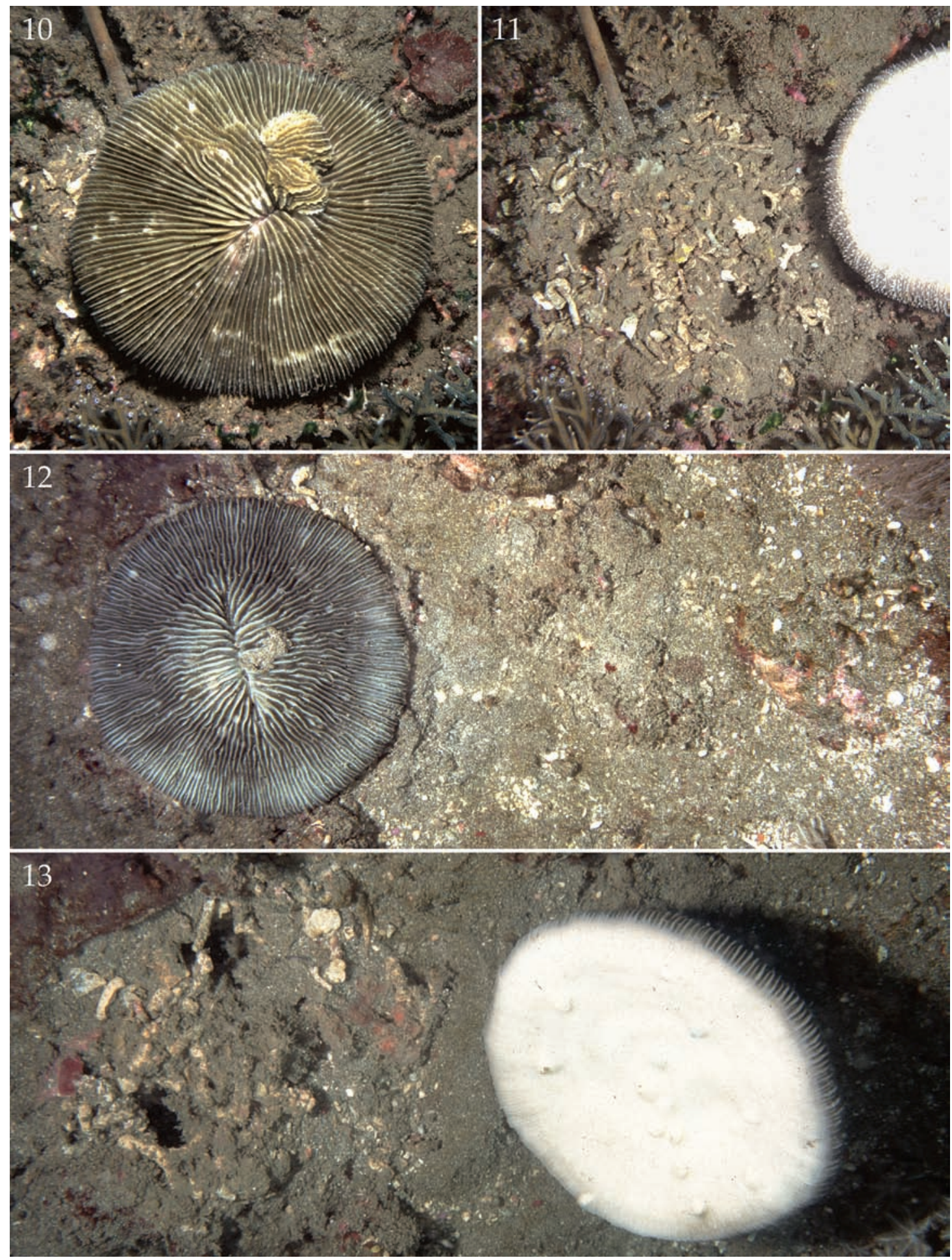

Figs 10-13. Habitats of Epitoniidae (continued); sediment with two burrows under free-living mushroom corals, SW Sulawesi, Indonesia. 10-11, Lithophyllon repanda, in situ (10) and removed (11) to show two circular burrows; 12-13, Pleuractis granulosa, in situ (12) and removed (13) to show two circular burrows. 

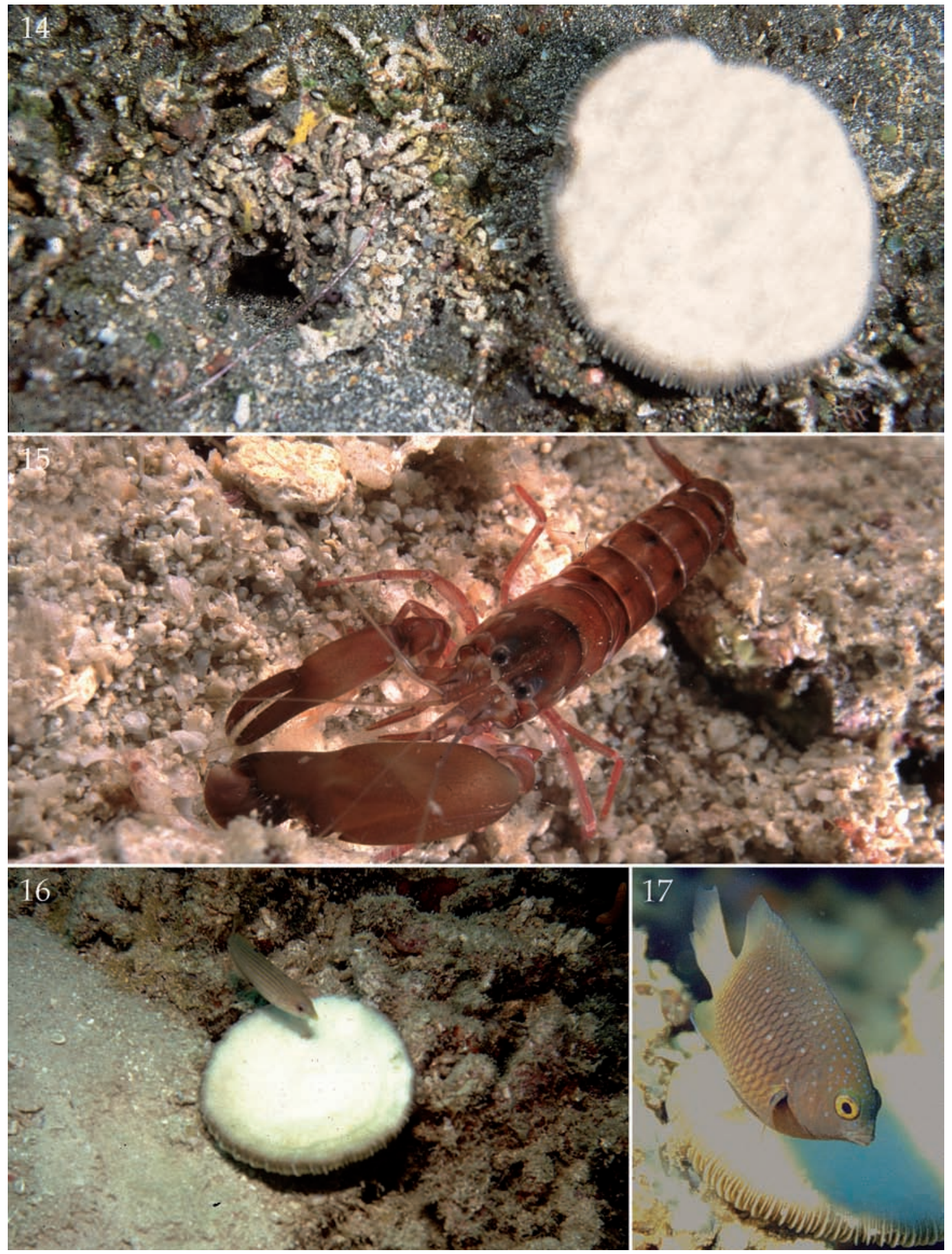

Figs 14-17. Possible predators of epitoniids in Indonesia. 14, Fungia fungites removed to show a circular burrow; 15, a shrimp, Alpheus frontalis, under a free-living Ctenactis echinata; 16, a wrasse, Halichoeres melanurus, monitoring an overturned fungiid; 17, a damselfish, Plectroglyphidodon lacrymatus, monitoring an overturned fungiid. Locations: 14, Bali; 15-17, SW Sulawesi. 
Table 1. Epitoniid species and their fungiid host species recorded at various Indo-West Pacific localities.

Epitoniid snail Fungiid host species

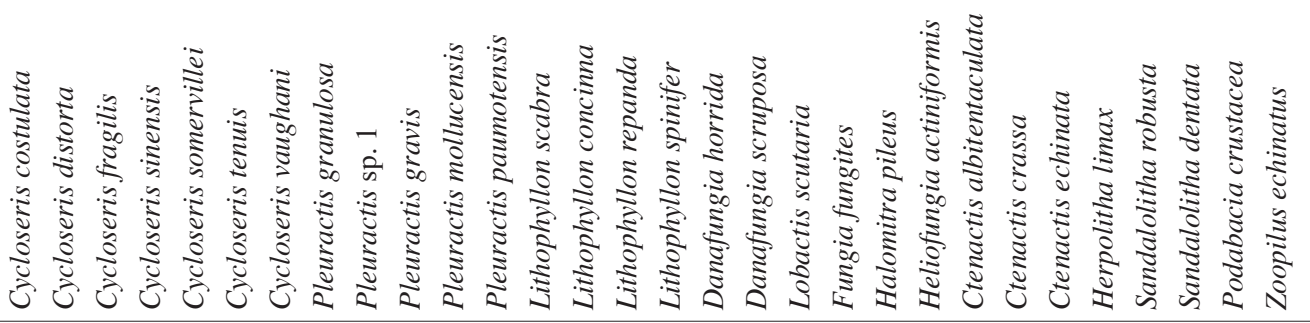

Epifungium

E.pseudolochi

E. lochi

E. adgranulosa

E. marki

E. adgravis

E. nielsi

E. adscabra

E. ulu

E. hoeksemai

E.twilae

E.pseudotwilae

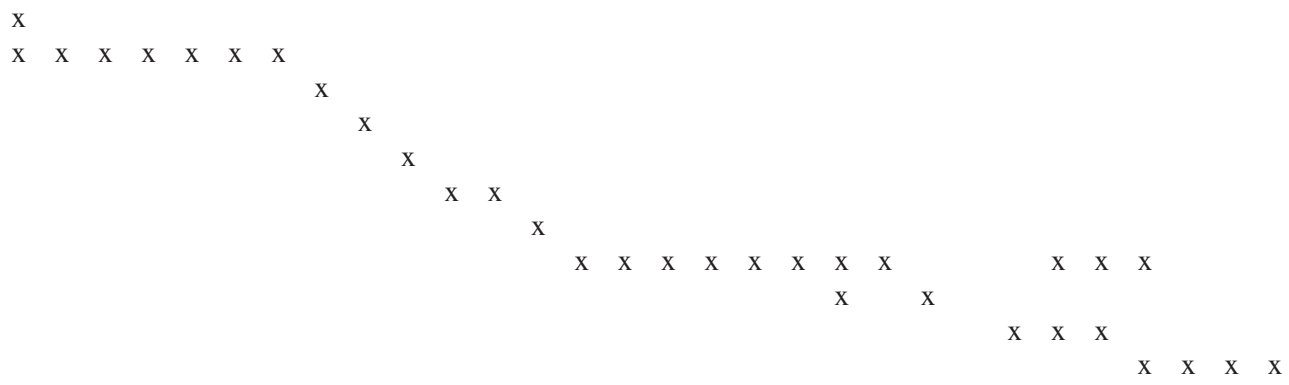

Epitonium

E. crassicostatum $\quad \mathrm{X}$

E. graviarmatum

X

Surrepifungium

S. costulatum

S. ingridae

S. oliverioi

S. patamakanthini

(Hoeksema and Koh, 2009). The corals were counted within a distance of one meter at both sides along the tape guided by a $1 \mathrm{~m}$ long aluminium rod. When less than 100 corals were found along the first $100 \mathrm{~m}$, the transect length was extended to reach this number. Fungiid densities and infestation rates based on presence/absence data were calculated for each transect and site. The number of snails per host coral was not considered important because they were occurring as single individuals or in clusters of snails of varying size, usually together with spawn (egg capsules sensu Robertson, 1994). The infestation rates were plotted against the fungiid densities. About 4,500 fungiids were identified to species level to get an indication of the species composition along the transect. Based on these species compositions and the total number of corals in the transects, the approximate number of specimens that was searched for each fungiid species was calculated. These numbers were used to calculate the infestation rates for the most common epitoniid species.

\section{Measurement of coral sizes}

Infested corals in the Spermonde Archipelago were divided and recorded in eight size classes measured in occupied substrate area $(<10,10-25,25-50,50-100$, $100-150,150-200,200-300$, and $>300 \mathrm{~cm}^{2}$ ), by placing them on plastic boards with the outlines of coral surfaces of 10, 25, 50, 100, 150, 200 and $300 \mathrm{~cm}^{2}$ drawn on them. To fit variable fungiid contour shapes, boards were made for corals varying from circular to oval and elongated with length/width ratios of 1, 1.5, 2, 3 and 4, respectively.

In order to compare the size of infested vs. noninfested corals, specimens were selected of the most 


\begin{tabular}{lrlll}
\hline \multicolumn{5}{c}{ Epitoniid } \\
\cline { 3 - 5 } Fungiid host species & \multicolumn{1}{l}{ n } & E. ulu & E.pseudotwilae E. twilae \\
\hline Danafungia horrida & 280 & 0.7 & 0.0 & 0.0 \\
Danafungia scruposa & 401 & 1,0 & 0.0 & 0.0 \\
Fungia fungites & 759 & 1.5 & 0.0 & 0.0 \\
Lobactis scutaria & 125 & 1.6 & 0.0 & 0.0 \\
Lithophyllon concinna & 791 & 3.7 & 0.0 & 0.0 \\
Lithophyllon repanda & 2098 & 2.2 & 0.0 & 0.0 \\
Ctenactis echinata & 415 & 0.2 & 0.0 & 1.0 \\
Herpolitha limax & 393 & 0.0 & 0.0 & 6.6 \\
Sandalolitha robusta & 173 & 0.0 & 4.1 & 0.0 \\
Zoopilus echinatus & 136 & 0.0 & 7.4 & 0.0 \\
\hline
\end{tabular}

Table 2. Infestation rate (\%) of fungiid populations by three Epifungium species (SW Sulawesi).

\begin{tabular}{|c|c|c|c|c|}
\hline Epitoniid species & $\begin{array}{l}\text { Positio } \\
\text { buried }\end{array}$ & $\begin{array}{l}\text { lative to host } \\
\text { on sand }\end{array}$ & on coral & Depth $(\mathrm{m})$ \\
\hline \multicolumn{5}{|l|}{ Epidendrium } \\
\hline E. aureum & & $\mathrm{x}$ & $\mathrm{x}$ & $2-28$ \\
\hline E. sordidum & & $\mathrm{x}$ & $\mathrm{x}$ & $3-35$ \\
\hline \multicolumn{5}{|l|}{ Epifungium } \\
\hline E. adgranulosa & & $\mathrm{x}$ & $\mathrm{x}$ & $3-18$ \\
\hline E. adgravis & & $\mathrm{x}$ & $\mathrm{x}$ & $3-30$ \\
\hline E. hoeksemai & $\mathrm{x}$ & $\mathrm{x}$ & $\mathrm{x}$ & $1-20$ \\
\hline E. lochi & & $\mathrm{x}$ & $\mathrm{x}$ & $3-27$ \\
\hline E. nielsi & & $\mathrm{x}$ & $\mathrm{x}$ & $4-36$ \\
\hline E. ulu & & $\mathrm{x}$ & $\mathrm{x}$ & $1-35$ \\
\hline E. adscabra & & & $\mathrm{x}$ & $3-18$ \\
\hline E. hartogi & & & $\mathrm{x}$ & $9-18$ \\
\hline E. marki & & & $\mathrm{x}$ & $15-28$ \\
\hline E.pseudolochi & & & $\mathrm{x}$ & $20-30$ \\
\hline E.pseudotwilae & & & $\mathrm{x}$ & $4-25$ \\
\hline E.twilae & & & $\mathrm{x}$ & $5-38$ \\
\hline \multicolumn{5}{|l|}{ Epitonium } \\
\hline E. crassicostatum & $?$ & $?$ & $?$ & 9 \\
\hline E. graviarmatum & $?$ & $?$ & $?$ & 35 \\
\hline \multicolumn{5}{|l|}{ Surrepifungium } \\
\hline S. costulatum & $\mathrm{x}$ & $\mathrm{x}$ & & $3-18$ \\
\hline S. ingridae & $\mathrm{x}$ & $\mathrm{x}$ & & $1-26$ \\
\hline S.oliverioi & $\mathrm{x}$ & $\mathrm{x}$ & & $4-38$ \\
\hline S. patamakanthini & $\mathrm{x}$ & $\mathrm{x}$ & & $5-18$ \\
\hline
\end{tabular}

Table 3. Depth range and position of epitoniid snails relative to the coral host recorded at various Indo-West Pacific 1ocalities: buried in sandy substratum underneath, living on sand underneath or on coral surface. abundant host species (Hoeksema, 1990), i.e. Lithophyllon concinna (Verrill, 1864), L. repanda (Dana, 1846), and Herpolitha limax (Esper, 1797), which were the most frequently infested by the most common epitoniids, i.e. Epifungium ulu Pilsbry, 1921, and E. twilae (Gittenberger and Goud, 2000 in Gittenberger et al., 2000). The size classes of the corals were recorded at 3-18 m depth at W Kudingareng Keke, regardless of their infestation rate. The null-hypothesis that infestations by E. ulu and E. twilae are not related to coralsize, was tested by Chi-square against three alternative hypotheses, i.e. [1] coral size influences the probability of being infested, [2] host size is positively correlated with epitoniid shell size, and/or [3] host size is positively correlated with the percentage of infestations with epitoniid spawns. 


\section{Overturned host corals}

Free-living fungiids are known to occasionally get overturned (Hoeksema, 1988, 2004). To investigate how this may affect epitoniid snails underneath the corals, 16 fungiid host corals of various species with snails and/or spawns of Epifungium ulu were carefully turned upside-down at 6-12 m depth on the reef slope NW of Langkai. After two hours and after two days the numbers of epitoniids and spawns were counted that were still present. Because the time available to find as many infected corals as possible was limited and the identity of the hosts was not relevant for the experiment, there was no preference with regard to host species.

In addition, two host corals with snails and spawns of Epifungium ulu and one with snails and spawns of E. twilae were placed upside-down, next to each other on the reef slope of W Kudingareng Keke. The specimens were observed from a distance of about 3 meters for 30 minutes to check whether any animals would predate on them.

It has been hypothesized that the overturning of a fungiid coral from an upright position to upside-down and back to upright, depends upon its size and form (Hoeksema, 1988). The rate at which this may happen was studied experimentally in the Spermonde Archipelago, using populations of 12 species, varying in shape from circular, viz. Danafungia horrida (Dana, 1846), D. scruposa (Klunzinger, 1879), Fungia fungites (Linnaeus, 1758), Lithophyllon concinna (Verrill, 1864), L. repanda (Dana, 1846), and L. scabra (Döderlein, 1901), and oval, viz. Lobactis scutaria (Lamarck, 1801), Pleuractis gravis (Nemenzo, 1955) and P.paumotensis (Stutchbury, 1833), to elongated, viz. Ctenactis echinata (Pallas, 1766), Herpolitha limax (Esper, 1797) and Polyphyllia talpina (Lamarck, 1801). With a waterproof pen, 360 quadrants of $22 \times 25$ $\mathrm{cm}^{2}, 24$ quadrants of $30 \times 30 \mathrm{~cm}^{2}, 24$ quadrants of $20 \times 35 \mathrm{~cm}^{2}$ and 24 quadrants of $25 \times 40 \mathrm{~cm}^{2}$, were drawn and numbered on two orange, plastic cover cloths, which were fastened with pegs at a depth of 18 $\mathrm{m}$ on a slope of approximately $15^{\circ}$ at W Kudingareng Keke reef. For each of the 12 species, 24 specimens (size class $25-100 \mathrm{~cm}^{2}$ ) were put in upright position in the $22 \times 25 \mathrm{~cm}^{2}$ quadrants. In addition, 24 corals of Lithophyllon repanda (size class $100-150 \mathrm{~cm}^{2}$ ) were placed in $30 \times 30 \mathrm{~cm}^{2}$ quadrants, 24 Herpolitha limax corals (size class $100-200 \mathrm{~cm}^{2}$ ) were placed in $20 \times 35$ $\mathrm{cm}^{2}$ quadrants, and $24 \mathrm{H}$. limax specimens (size class
$200-300 \mathrm{~cm}^{2}$ ) were placed in $25 \times 40 \mathrm{~cm}^{2}$ quadrants. The corals that had turned themselves over within three and within ten days were recorded. The experiment was repeated with all corals in upside-down position at the start. After four hours and after two days it was recorded how many had returned to an upright position.

The percentage of specimens in overturned position under natural conditions was recorded for the 23 most common fungiid species in the Spermonde Archipelago on the basis of at least 100 randomly checked specimens per species.

\section{Results}

\section{Abundance of infestations}

About $1.5 \%$ of all examined mushroom corals $(\mathrm{n}=60,000)$ appeared infested by epitoniids that belonged to the following 20 species (see Gittenberger and Gittenberger, 2005): Surrepifungium costulatum (Kiener, 1839); (n=103 infested hosts), S. ingridae (Gittenberger and Goud, 2000) $(\mathrm{n}=43)$, S. Oliverioi (Bonfitto and Sabelli, 2001) $(\mathrm{n}=10)$, S. patamakanthini Gittenberger and Gittenberger, $2005(\mathrm{n}=27)$, Epidendrium aureum Gittenberger and Gittenberger, 2005 (n=52), E. sordidum Gittenberger and Gittenberger, $2005(\mathrm{n}=22)$, Epifungium adgranulosa Gittenberger and Gittenberger, $2005(\mathrm{n}=20)$, E. adgravis Gittenberger and Gittenberger, $2005(\mathrm{n}=38)$, E. hoeksemai (Gittenberger and Goud, 2000) $(\mathrm{n}=34)$, E. lochi (Gittenberger and Goud, 2000) $(\mathrm{n}=36)$, E. nielsi Gittenberger and Gittenberger, 2005 (n=83), E. ulu Pilsbry, 1921 (n=191), E. adscabra Gittenberger and Gittenberger, $2005(\mathrm{n}=22), E$. hartogi (Gittenberger, 2003) $(\mathrm{n}=10)$, E. marki Gittenberger and Gittenberger, $2005(\mathrm{n}=4)$, E. pseudolochi Gittenberger and Gittenberger, $2005(\mathrm{n}=5)$, E. pseudotwilae Gittenberger and Gittenberger, $2005(\mathrm{n}=68)$, E. twilae (Gittenberger and Goud, 2000) (n=98), Epitonium crassicostatum Gittenberger and Gittenberger, $2005(\mathrm{n}=1)$, and E. graviarmatum Gittenberger and Gittenberger, $2005(\mathrm{n}=1)$. The 870 recorded infestations involved 1,657 snails, on average about two per coral while $283(32.5 \%)$ of the hosts also had epitoniid spawns. Approximately 2,500 free-living fungiids were found in an upside-down position and only one of these had only spawns without any snail. Along the transects off SW Sulawesi, 3.7\% of all corals $(n=7,219)$ were found to be infested by epitoniids. 


\section{Associations}

Thirty fungiid species were found to host wentletrap snails (Table 1). Two abundant mushroom coral species with $>1000$ specimens inspected were never found associated with wentletraps, i.e. Polyphyllia talpina (Lamarck, 1801) and Heliofungia fralinae (Nemenzo, 1955). Occasionally snails belonging to the species Epifungium ulu, E. hoeksemai, E. twilae and E. pseudotwilae were found co-habitating a single host coral with snails of the species Surrepifungium costulatum, S. ingridae, S.oliverioi and S. patamakanthini, in which case the first was always attached to the coral and the latter occurred on or inside the sediment underneath.

The infestation rates shown by the most common epitoniids in the Spermonde Archipelago varied per host species, with maxima of $3.7 \%$ on Lithophyllon concinna by Epifungium ulu, $7.4 \%$ by E. pseudotwilae on Zoopilus echinatus Dana, 1846, and $6.6 \%$ by $E$. twilae on Herpolitha limax (Table 2).

Five Epifungium species are host-specific (Table 1), whereas the five other ones have at least two hosts. On the other hand, 24 fungiids are host for only one Epifungium, whereas only five mushroom coral species are a habitat for more than one Epifungium (Table 1). These do not necessarily compete for space, since the relatively small Cycloseris costulata hosts two Epifungium species, but in allopatry: E. pseudolochi in the Red Sea and E. lochi from the Maldives to Palau (Gittenberger and Gittenberger, 2005). The two most generalistic species within the genus Epifungium are $E$. $l o c h i$ and $E$. ulu but the first only inhabits seven closely related free-living Cycloseris species, while E. ulu lives with eight fungiid host species that are less closely related (Table 1). E. hoeksemai is associated with two remotely related host coral species, i.e. Fungia fungites and Heliofungia actiniformis. Its habitat preferences are unusual, since it is the only epitoniid that was variably found buried in the sand, on the substrate, or on the coral's surface (Table 3).

Epifungium hartogi was commonly observed in association with two euphylliid coral species, Plerogyra diabolotus Ditlev, 2003, and P. simplex Rehberg, 1892, but not with Plerogyra sinuosa (Dana, 1846), even though this was by far the most common euphylliid at most localities. Epidendrium aureum and E. sordidum occurred both sympatrically and syntopically in mixed populations directly next to or on the dendrophylliid Tubastraea sp. (Gittenberger and Gittenberger, 2005: Figs 58-59).

\section{Coral densities and infestation rates}

Infestation rates varied significantly between sites $\left(X^{2}=63.4, p<0.001\right.$; Fig. 18) and transects $\left(X^{2}=21.7\right.$, $\mathrm{p}<0.025$; Fig. 19). At nearly all sites, with the exception of W Lae-Lae, the coral densities and the infestation percentages were negatively correlated $(r=-0.43$, $\mathrm{p}<0.001)$. When the W Lae-Lae record is excluded the correlation becomes even stronger $(r=-0.80, p<0.001)$. A similar strong negative correlation $(\mathrm{r}=-0.98, \mathrm{p}<0.001)$, was found for the coral densities and the percentages of infestation by Epifungium ulu at $\mathrm{E}$ and W Kudingareng Keke. Only data from Kudingareng Keke were used in the analysis, because only there large numbers of corals $(n>100)$ could be searched in all transects. These findings are supported by observations in Egypt, the Maldives, Thailand and Palau, where infestation rates of over $50 \%$ were repeatedly found at sites with very low coral densities, i.e. $\leq 10$ corals / dive. At sampled sites where over 100 corals were found, infestation percentages never exceeded $5 \%$.

\section{Depth ranges}

No correlation between infestation rate and depth was found for Epifungium ulu within a depth range of 1-35 m (Fig. 19, Table 3). Specimens of E. lochi, E. adgravis, E. marki and E. pseudolochi usually occur deeper than those of other species (Table 3) because of the depth preference of their host corals (Table 1). On the relatively rare occasions that these host species were found in shallower water, the associated epitoniids were also present, but because of their low densities no depth-related correlation could be calculated for these species. The only indication of a depth preference was found for E. twilae. None of its 107 infested host corals in the Maldives, Thailand and Indonesia was found deeper than $24 \mathrm{~m}$, where the potential hosts Ctenactis crassa (Dana, 1846), C. echinata (Pallas, 1766) and Herpolitha limax (Esper, 1797) were rare, whereas all four lots of epitoniids in the Red Sea were found at 30-38 m depth (e.g. E. twilae in Table 3). Ctenactis was absent here, but $H$. limax was common at 6-45 m depth with $0 \%$ infestation by $E$. twilae $(\mathrm{n}=50)$ at $6-30 \mathrm{~m}$ depth and $33 \%$ infestation $(\mathrm{n}=12)$ at $30-45 \mathrm{~m}$, although the maximum depth with E. twilae here was $38 \mathrm{~m}$ (Table 3).

\section{Substrates and attachment}

Mushroom corals in the Spermonde Archipelago on flat substrates and those above crevices or burrows 


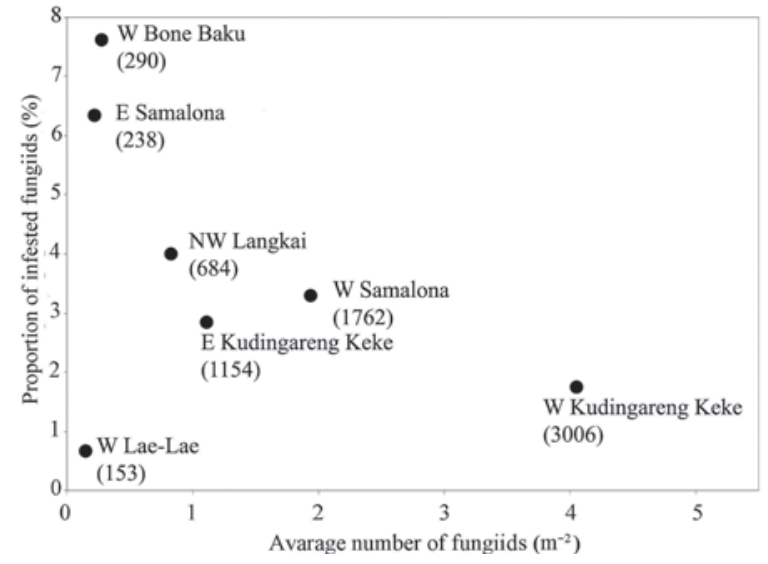

Fig. 18. Infestation rates of mushroom corals (\%) plotted against mushroom coral density in the Spermonde Archipelago, SW Sulawesi, Indonesia; $n$ values are indicated (in brackets).

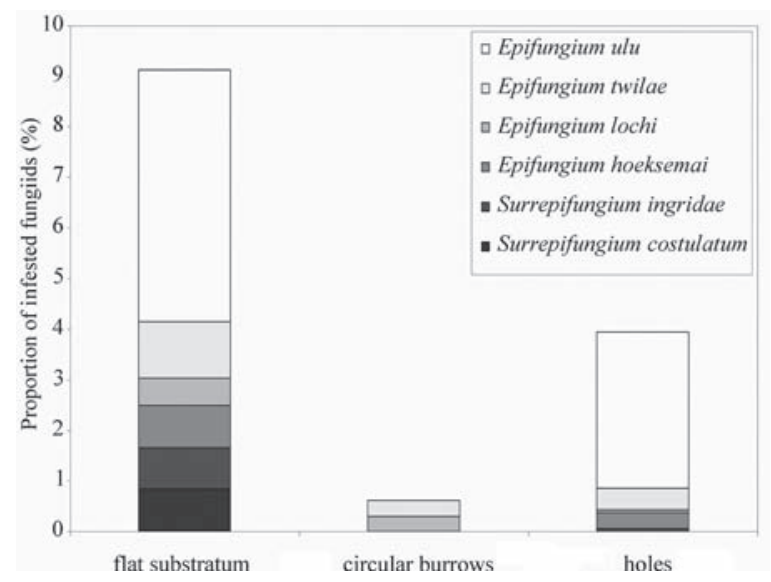

Fig. 20. Percentages of fungiid corals on three substrate types in the Spermonde Archipelago: on flat sediment $(n=362)$, on sediment with circular burrows $(n=329)$ or with crevices $(n=1,620)$; each of which were infested by Surrepifungium costulatum $(\mathrm{n}=3), S$. ingridae $(\mathrm{n}=5)$, Epifungium adgranulosa $(\mathrm{n}=1)$, E. adgravis $(\mathrm{n}=2)$, E. adscabra $(\mathrm{n}=9)$, E. hoeksemai $(\mathrm{n}=4)$, E. lochi $(\mathrm{n}=4)$, E. nielsi $(\mathrm{n}=9)$, E. pseudotwilae $(\mathrm{n}=5), E$. twilae $(\mathrm{n}=7)$ and E. ulu $(\mathrm{n}=47)$.

show different infestation rates (Fig. 20). Corals on flat substrate showed significantly higher infestation rates $\left(\mathrm{X}^{2}=14.9, \mathrm{p}<0.001\right)$, whereas those above a burrow were the least likely infested $\left(\mathrm{X}^{2}=14.8, \mathrm{p}<0.001\right)$. Snails of Epifungium adgranulosa, E. adgravis, E. hoeksemai, E. lochi, E. nielsi and E. ulu, were found on both the substrate and on the underside of their fungiid host (Table 3). E. ulu specimens underneath hosts dwelling on a flat bottom $(n=26)$ were encountered more frequently attached to the host (96\%) than

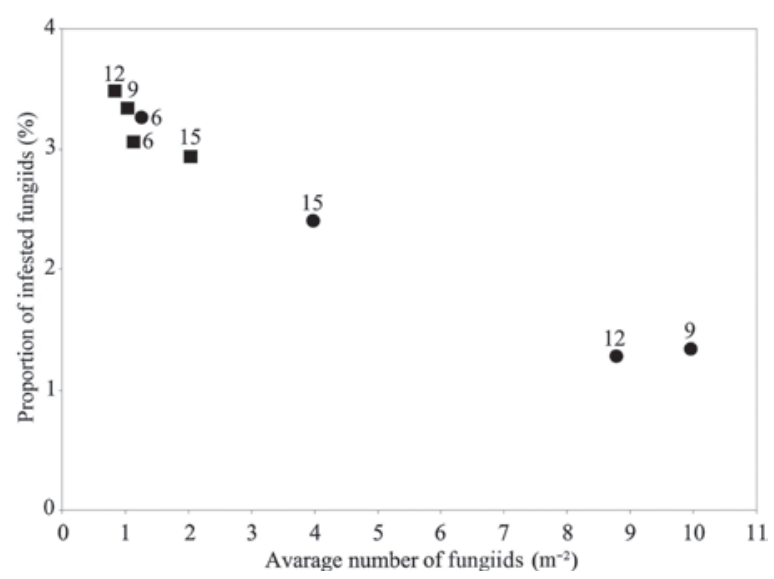

Fig. 19. Infestation rates of mushroom corals by Epifungium ulu $(\%)$ plotted against mushroom coral density along transects at 6,9,12 and $15 \mathrm{~m}$ depth on the east (squares) and west (dots) side of Kudingareng Keke Island, SW Sulawesi, Indonesia (see Fig. 2). Total $n=3,671$ corals; a minimum number of 172 corals per transect. Transect depths are indicated next to the data points.

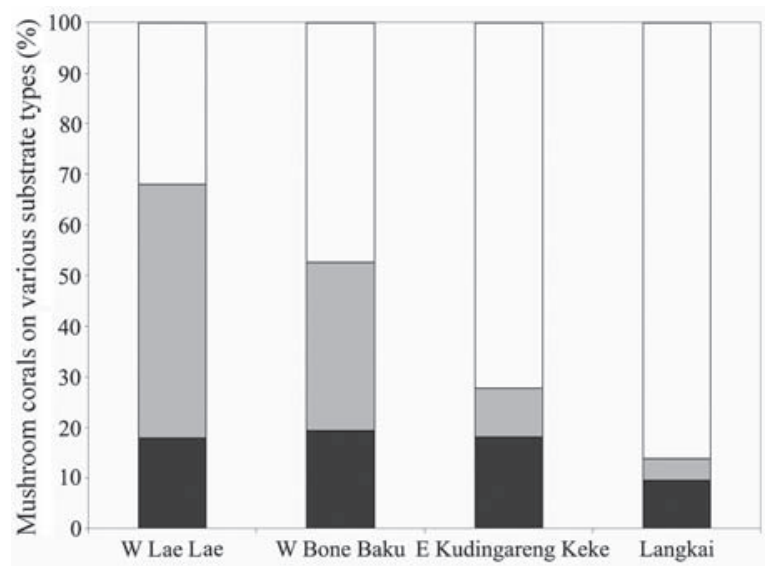

Fig. 21. Percentages of fungiid corals at W Lae-Lae ( $\mathrm{n}=184), \mathrm{W}$ Bone Baku ( $\mathrm{n}=289)$, E Kudingareng Keke $(\mathrm{n}=1,154)$ and Langkai $(n=84)$, on flat sediment (white), sand with burrows (grey) or sediment with burrows (black).

lying on top of the substrate $\left(X^{2}=22.2, p<0.001\right)$, whereas regarding those on a substrate with crevices $(n=66)$ no significant preference was found for either $\left(\mathrm{X}^{2}=1.2, \mathrm{p}=0.3\right)$ with $44 \%$ attached to the coral. Shells and spawns were usually attached to the substrate by mucus threads. These threads were noted to be extremely elastic and strong enough to pull specimens back to their hosts over distances up to $50 \mathrm{~cm}$.

The proportions of corals lying on either a flat bottom, a burrow or crevices vary significantly between 


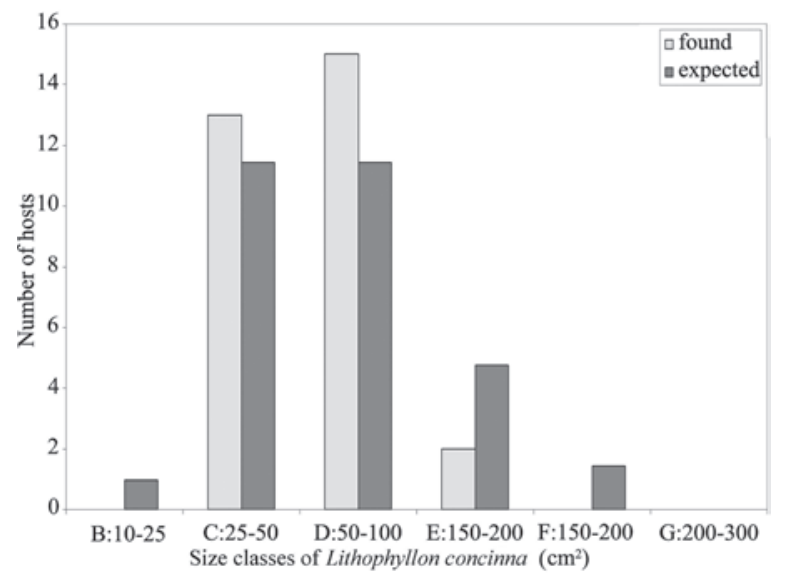

Fig. 22. Numbers of specimens of Lithophyllon concinna in the size classes 10-25, 25-50, 50-100, 100-150, 150-200 and 200$300 \mathrm{~cm}^{2}$ observed as infested by Epifungium ulu in the Spermonde Archipelago (see Fig. 2), next to the expected numbers when infestations are random, based on the coral size distribution of L. concinna specimens off W Kudingareng Keke, Spermonde Archipelago $(n=63)$.

SW Sulawesi sites (Fig. 21; $X^{2}=412.4, p<0.001$ ). Although the number of corals on a flat substrate remained similar, a burrow was observed more frequently at localities closer to the coast and a substrate with crevices was most common further offshore.

At all SW Sulawesi sites (Fig. 1) mushroom corals above burrows did not host any epitoniids with only two exceptions. Burrows seemed to be more common in the sand underneath mushroom corals than in the sand around them. Gobies (Gobiidae) and goby shrimps (Alpheidae) were occasionally seen hiding underneath mushroom corals that revealed one or two burrows after being turned over. Individuals if two burrowing shrimp species were observed to push the mushroom coral quickly over the sand when it was blocking their escape routes: a specimen of $\mathrm{Al}$ pheus frontalis $\mathrm{H}$. Milne Edwards, 1837 (Caridea: Alpheidae; Fig. 15) underneath Ctenactis echinata at Palau and a specimen of Axiopsis sp. (Thalassinidea: Axiidae) underneath a Herpolitha limax coral in the Spermonde Archipelago, Indonesia.

\section{Coral sizes}

At the west side of Kudingareng Keke reef (SW Sulawesi), the infestation of Lithophyllon concinna $(\mathrm{n}=63)$ and L. repanda $(\mathrm{n}=84)$ by Epifungium ulu was examined in relation to the host's size and similarly for Herpolitha limax $(\mathrm{n}=153)$ infested by E. twilae

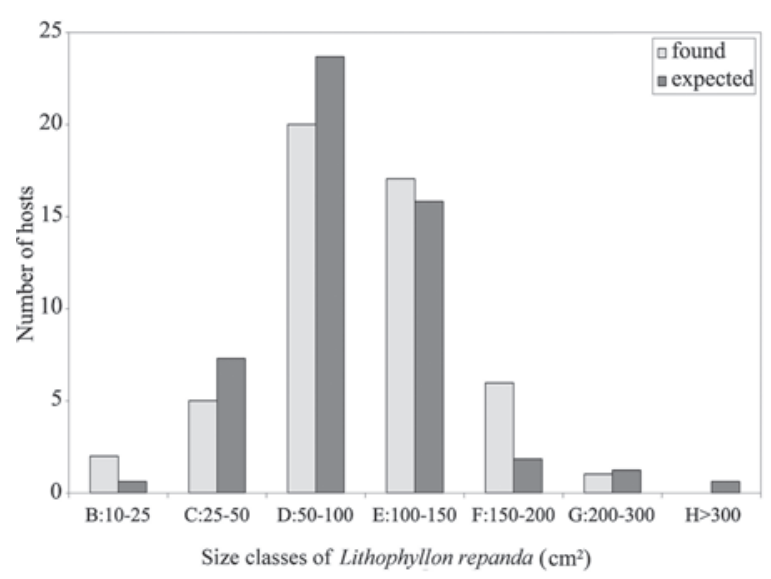

Fig. 23. Numbers of specimens of Lithophyllon repanda in the size classes 10-25, 25-50, 50-100, 100-150, 150-200, 200-300 and $>300 \mathrm{~cm}^{2}$ observed as infested by Epifungium ulu in the Spermonde Archipelago (see Fig. 2), next to the expected numbers when infestations are random, based on the coral size distribution of $L$. repanda specimens off W Kudingareng Keke, Spermonde Archipelago $(\mathrm{n}=84)$.

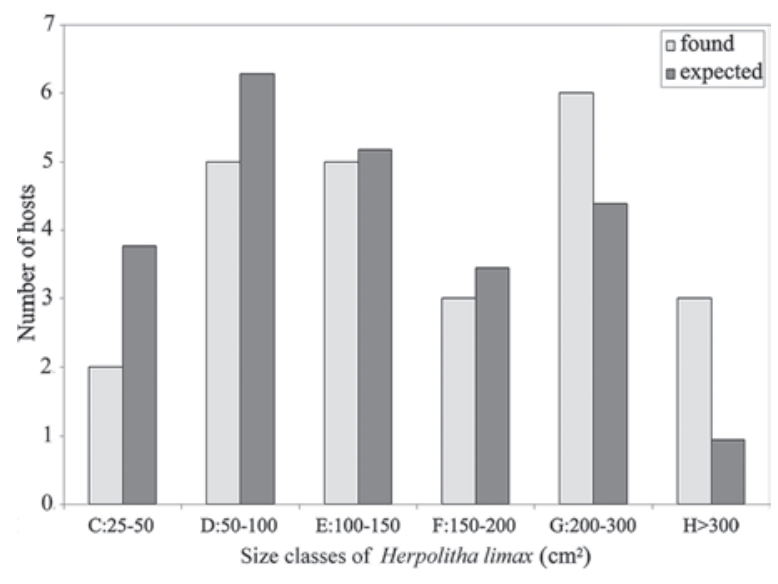

Fig. 24. Numbers of specimens of Herpolitha limax in the size classes $10-25 \mathrm{~cm}^{2}, 25-50 \mathrm{~cm}^{2}, 50-100 \mathrm{~cm}^{2}, 100-150 \mathrm{~cm}^{2}, 150-$ $200 \mathrm{~cm}^{2}, 200-300 \mathrm{~cm}^{2}$ and $>300 \mathrm{~cm}^{2}$ observed as infested by Epifungium twilae in the Spermonde Archipelago (see Fig. 2), next to the expected numbers when infestations are random, based on the coral size distribution of Herpolitha limax specimens off W Kudingareng Keke, Spermonde Archipelago $(n=153)$.

(Figs 22-24). E. ulu specimens were significantly more abundant underneath large specimens of Lithophyllon repanda (Fig. $23 ; \mathrm{X}^{2}=14.4, \mathrm{p}<0.001$ ) than would be expected randomly, whereas they were found less frequently under larger Lithophyllon concinna corals than at random, but this difference is not significant (Fig. 22; $\mathrm{X}^{2}=1.8, \mathrm{p}=0.20$ ). E. twilae 

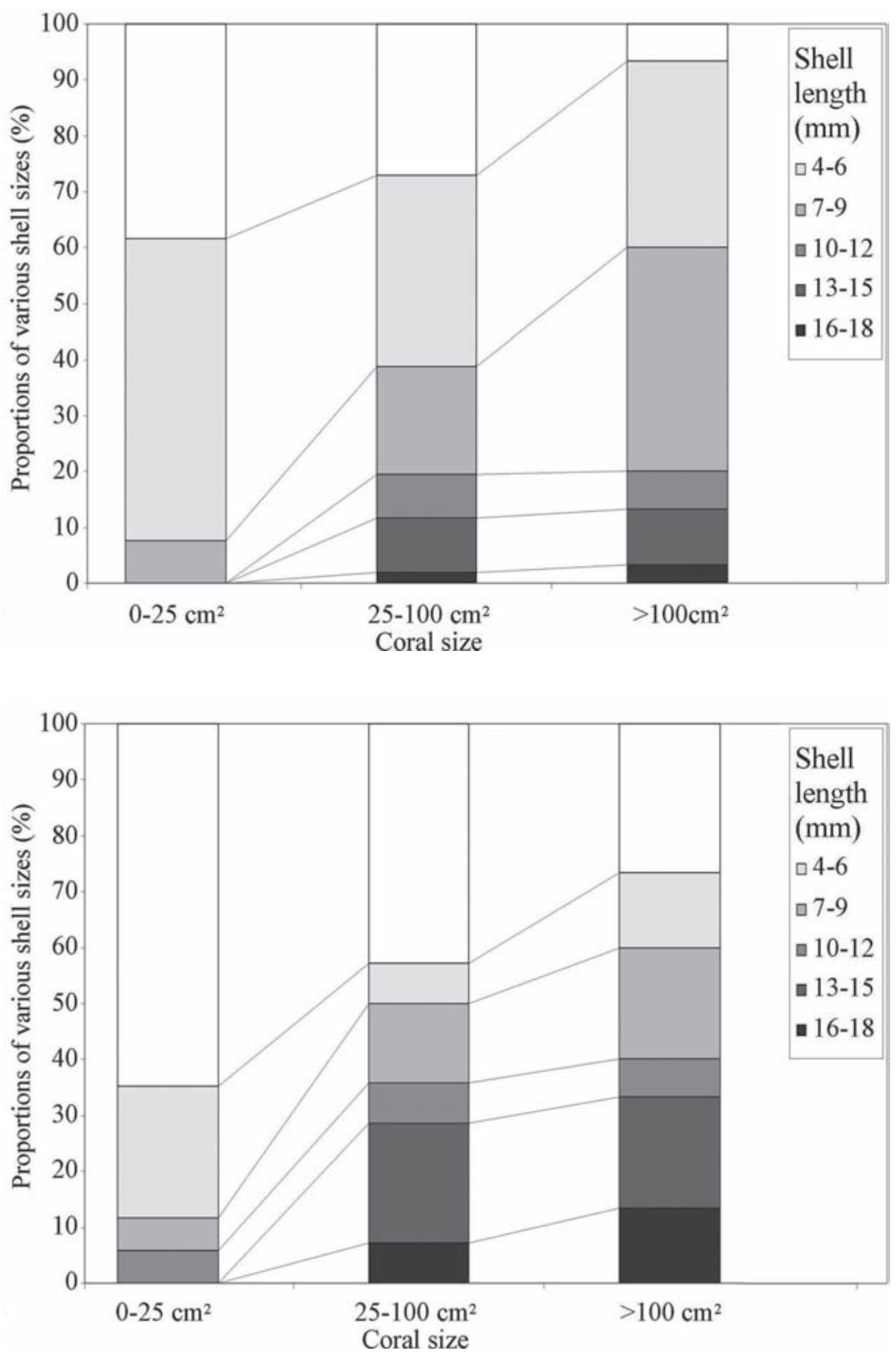

Fig. 25. The maximum shell lengths found in Epifungium ulu samples $(n=146)$ and their distributions in the size classes $0-25 \mathrm{~cm}^{2} \quad(\mathrm{n}=13), 25-100$ $\mathrm{cm}^{2}(\mathrm{n}=103)$ and $>100 \mathrm{~cm}^{2}(\mathrm{n}=30)$ of their coral hosts, in the Spermonde Archipelago, Indonesia.
Fig. 26. The maximum shell lengths found in Epifungium twilae samples $(\mathrm{n}=46)$ and their distributions in the size classes 0-25 ( $\mathrm{n}=17), 25-100 \quad(\mathrm{n}=14)$ and $>100 \mathrm{~cm}^{2}(\mathrm{n}=15)$ of their coral hosts in the Spermonde Archipelago, Indonesia. specimens occurred significantly more frequently underneath larger hosts (Fig. 24; $\mathrm{X}^{2}=4.7$, p $<0.05$ ). Larger corals are significantly more frequently infested by relatively large specimens of both E. ulu (Fig. 25; $\mathrm{X}^{2}=11.2, \mathrm{p}<0.025$ ) and E. twilae (Fig. 26; $\mathrm{X}^{2}=67.1$, $\mathrm{p}<0.001)$. Underneath larger host corals, spawns of both E. ulu (Table 4; $\left.\mathrm{X}^{2}=4.7, \mathrm{p}<0.05\right)$ and E. twilae (Table $4 ; \mathrm{X}^{2}=10.3, \mathrm{p}<0.05$ ) were found significantly more frequently than would be expected by chance.

\section{Overturned host corals}

No mushroom coral in overturned position $(\mathrm{n}=$ $\sim 2,000$ ) was observed to be infested by epitoniids. One single overturned coral was observed with epitoniid spawns of unknown identity. Fig. 28 illustrates the fate of 28 epitoniids and seven spawns that were initially attached to 16 coral hosts. During the overturning experiment, some snails were immediately 


\begin{tabular}{lllllll}
\hline \multicolumn{7}{c}{ Host coral size class } \\
\hline Epitoniids & $10-50 \mathrm{~cm}^{2}$ & $50-150 \mathrm{~cm}^{2}$ & & $>150 \mathrm{~cm}^{2}$ \\
\hline E. ulu & $\%$ & $\mathrm{n}$ & $\%$ & $\mathrm{n}$ & $\%$ & $\mathrm{n}$ \\
with spawn & 26 & 16 & 42 & 35 & 60 & 6 \\
without spawn & 74 & 46 & 58 & 48 & 40 & 4 \\
\hline $\begin{array}{l}\text { E.twilae } \\
\text { with spawn }\end{array}$ & $\%$ & $\mathrm{n}$ & $\%$ & $\mathrm{n}$ & $\%$ & $\mathrm{n}$ \\
without spawn & 17 & 3 & 29 & 4 & 65 & 11 \\
\hline
\end{tabular}

Table 4. Size distributions of Epifungium ulu and E. twilae samples with or without spawn on corals in the size classes $0-50 \mathrm{~cm}^{2}, 50-150 \mathrm{~cm}^{2}$ and $>150$ $\mathrm{cm}^{2}$ (SW Sulawesi).

Table 5. Overturning experiment at SW Sulawesi. Data are based on 24 specimens per species in each size class. Species ranking by number of overturned corals in size class $25-100 \mathrm{~cm}^{2}$.

\begin{tabular}{|c|c|c|c|c|}
\hline Fungiid species & Size class $\left(\mathrm{cm}^{2}\right)$ & Average length / width & Average weight (g) & $\begin{array}{l}\text { Number of overturned } \\
\text { corals }(n=24) \text { after } 2 \text { days }\end{array}$ \\
\hline Polyphyllia talpina & $25-100$ & 3.6 & 142 & 20 \\
\hline \multirow[t]{3}{*}{ Herpolitha limax } & $25-100$ & 2.2 & 127 & 11 \\
\hline & $100-200$ & 3.1 & 302 & 11 \\
\hline & $>200$ & 3.4 & 754 & 1 \\
\hline Lobactis scutaria & $25-100$ & 1.6 & 135 & 9 \\
\hline Pleuractis gravis & $25-100$ & 1.6 & 251 & 7 \\
\hline Pleuractis paumotensis & $25-100$ & 1.7 & 131 & 5 \\
\hline \multirow[t]{2}{*}{ Lithophyllon repanda } & $25-100$ & 1.1 & 127 & 5 \\
\hline & $100-150$ & 1.1 & 326 & 0 \\
\hline Ctenactis echinata & $25-100$ & 2.2 & 94 & 4 \\
\hline Danafungia scruposa & $25-100$ & 1.1 & 127 & 3 \\
\hline Lithophyllon scabra & $25-100$ & 1.1 & 75 & 3 \\
\hline Lithophyllon concinna & $25-100$ & 1.2 & 110 & 1 \\
\hline Danafungia horrida & $25-100$ & 1.0 & 163 & 1 \\
\hline Fungia fungites & $25-100$ & 1.1 & 93 & 0 \\
\hline
\end{tabular}

pulled from their hosts by currents or by fish, such as Labridae (e.g. Halichoeres melanurus (Bleeker, 1851) Fig. 16)) and Pomacentridae (e.g. Plectroglyphidodon lacrymatus (Quoy and Gaimard, 1825) (Fig. 17)). One of two corals that were still hosting epitoniids after two days, had returned to an upright position, whereas the other was situated inside a crevice, away from currents.

In the experiment in which three hosts were turned upside-down, i.e. two corals of Lithophyllon repan$d a$, each with two specimens and spawns of Epifungium ulu and one coral of Herpolitha limax with two $E$. twilae snails, all $E$. ulu were eaten or removed within 30 minutes by wrasses and damselfishes, while the E.twilae snails survived.

No significant differences in righting rate were found among the mushroom corals in the overturning experiment, since only three of the 360 fungiids (12 species $\times 24$ specimens +3 larger size classes $\times 24$ specimens) had turned over (upside-down) within 10 days. Among mushroom coral species significant differences in numbers of individuals had regained an upward position within two days $\left(\mathrm{X}^{2}=58.3, \mathrm{p}<0.001\right.$; Table 5). Corals of elongate species such as Polyphyllia talpina, Herpolitha limax and Lobactis scutaria showed much higher frequencies of righting than round corals, although almost all corals of the largest and heaviest size classes of H. limax and Lithophyllon repanda remained upside-down (Table 5). In SW Sulawesi, 1,109 out of 26,277 fungiids (4.2\%), were observed in upside-down position under natural conditions. These percentages differed significantly among species (Fig. 28; $X^{2}=202.1, p<0.001$ ). Corals of oval and round polystomatous species such as Sandalolitha robusta (Quelch, 1886) and Halomitra pileus (Linnaeus, 1758), were most frequently found in 


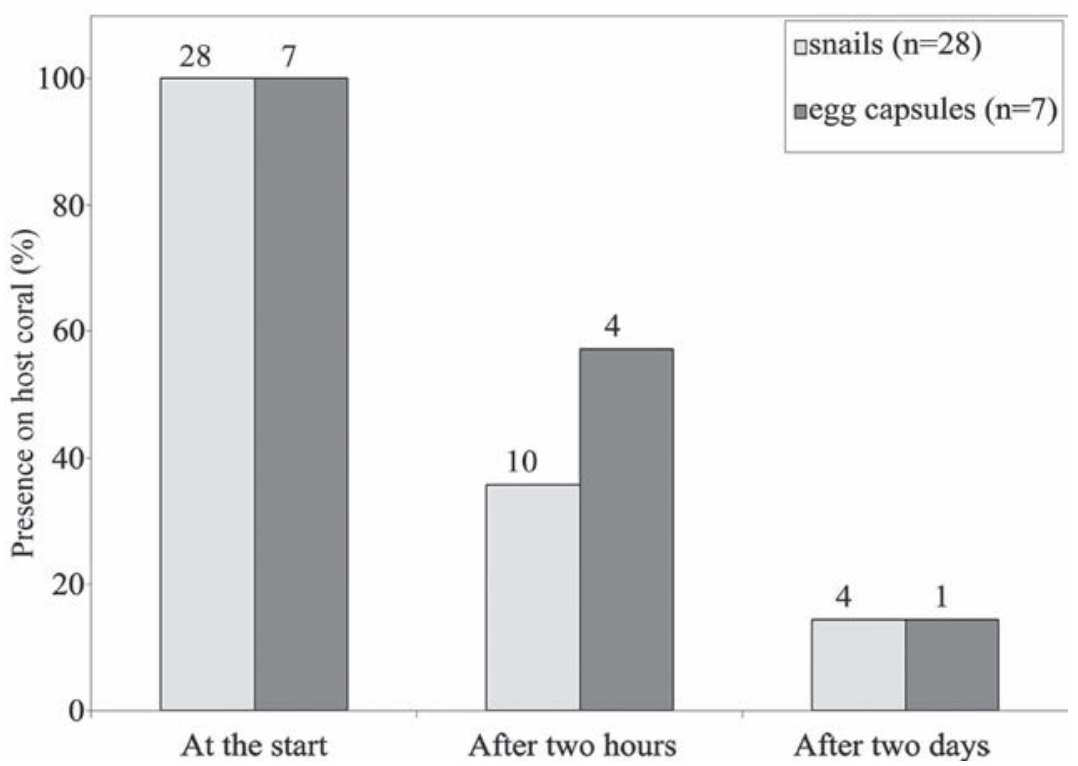

Fig. 27. Numbers of snails and spawns of Epifungium ulu that remained on the underside of the host corals after overturning; after two hours and after two days, off W Langkai (see Fig. 2).

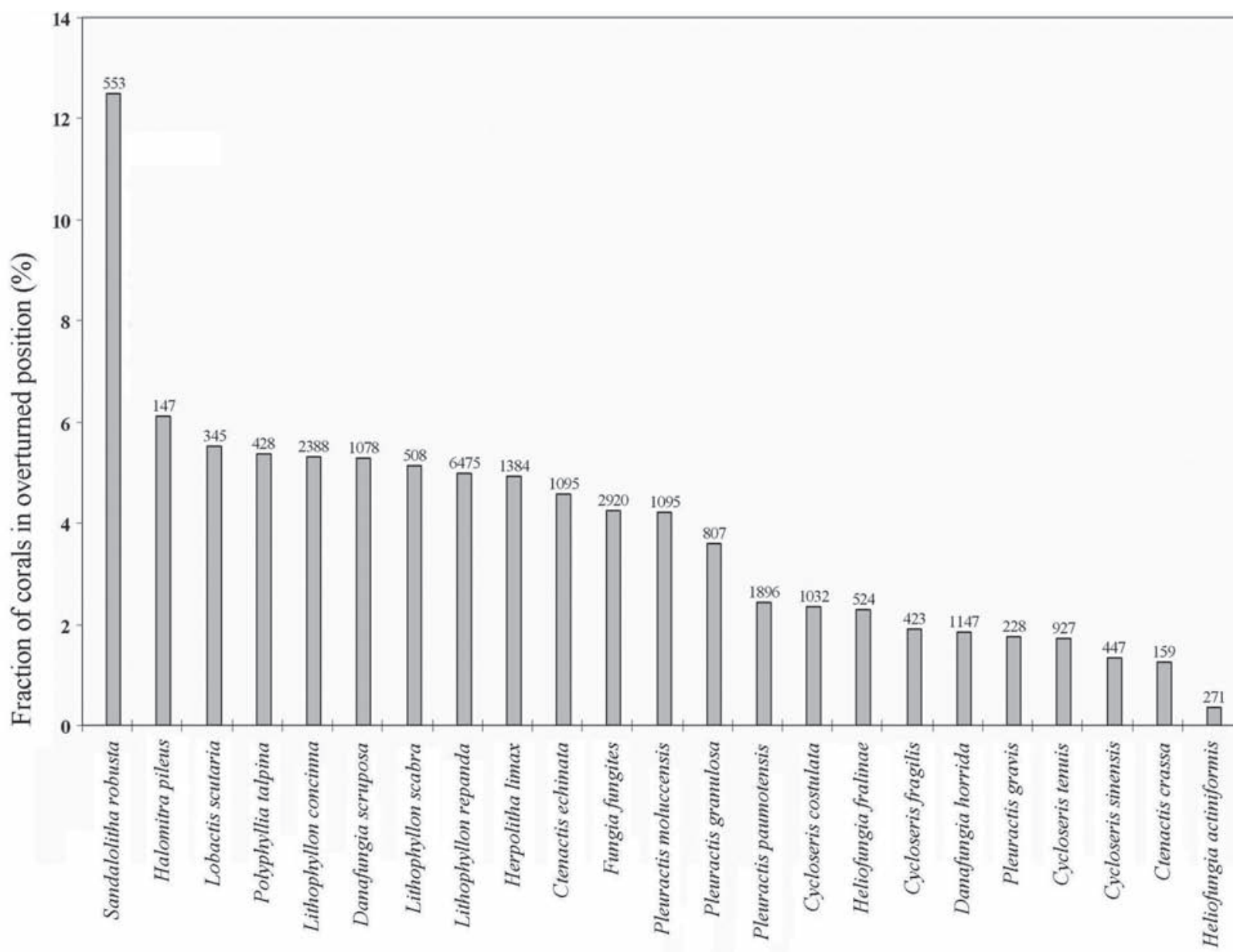

Fig. 28. Percentages of fungiid populations observed in overturned position in the Spermonde Archipelago (Fig. 2); n values are indicated per species. 
upside-down position (Fig. 28). Of all fungiids, Heliofungia actiniformis was most frequently found in upright position (Fig. 28). This species is well known for its righting capacity (Abe, 1939).

\section{Discussion}

\section{The trophic role of coral-associated epitoniids}

Unlike Bouchet and Warén (1985), we consider wentletrap snails to be highly specialised parasites because they exploit their hosts as habitat and food source for a relatively long time during their short life, even though their hosts are not clearly harmed, whereas predators can be distinguished by their momentary association with a prey and the rapid and destructive consumption of whole individuals or large fragments (Castro, 1988). Epitoniids on corals live indeed a much shorter life than their hosts and remain constantly in contact with them, or very close, like buried in the sediment underneath. In contrast to short-lived epitoniids that stick to a single host individual during their entire life, predatory Drupella species (Johnson and Cumming, 1995; Claremont et al., 2011) are known to have a life span of several years (Black and Johnson, 1994), during which they are able to kill many corals while occurring in small groups or large aggregations (Turner, 1994; Cumming, 1999; Morton and Blackmore, 2009; Hoeksema et al., 2013). The ecological strategy of epitoniids is more similar to that of ovulid snails on Octocorallia and Antipatharia (Schiaparelli et al., 2005; Reijnen et al., 2010) and Pedicularia snails on stylasterid corals (Goud and Hoeksema, 2001; Braga-Henriques et al., 2011) in which the hosts become at most partly eaten over a long time period by a few parasites but not entirely consumed in a short time by a single large predator or a pack of smaller ones.

A fundamental condition for the identification of coral-associated molluscs consists of a good knowledge of the available host coral species (e.g. Gittenberger and Gittenberger, 2005; Hoeksema et al., 2012a), as also demonstrated for the endoparasitic gastropod genus Leptoconchus Rüppell, 1834 (Coralliophilidae) (Hoeksema and Gittenberger, 2008; Gittenberger and Gittenberger, 2011), and coral-boring mussels (Mytilidae) of the genera Fungiacava Goreau et al., 1968, and Leiosolenus Carpenter, 1856 (Hoeksema and Kleemann, 2002; Kleemann and Hoeksema, 2002; Owada and Hoeksema, 2011).
All common free-living fungiid species were found in association with epitoniids except for Heliofungia fralinae and Polyphyllia talpina (Table 1). These two species can be distinguished from most other fungiids because of their relatively long tentacles, although the fungiid with the longest tentacles, Heliofungia actiniformis (Quoy and Gaimard, 1833), was found in association with two species, i.e. Epifungium hoeksemai and Surrepifungium patamakanthini. It remains unclear why $H$. fralinae and $P$. talpina have not been found infested even though more than 1,000 specimens of each were examined. When the entirely recorded associated fauna of mushroom corals is taken into account, $H$. fralinae appears to have no known associate at all, whereas $P$. talpina has a record of seven associated species as compared to at least 21 recorded for $H$. actiniformis (Bos, 2012; Hoeksema et al., 2012a). Therefore, the absence of epitoniids on $H$. fralinae is not unique and may perhaps be related to toxins excreted by this particular species as a defense mechanism in interspecific coral interactions (Sheppard, 1979; Thomason and Brown, 1986; Abelson and Loya, 1999).

In the present study, some Epifungium and Surrepifungium species are considered specialists by being associated with a monophyletic group of host corals or just a single host species, whereas others are generalists by having associations with various coral species that are distantly related (Gittenberger et al., 2011). Hence, the four burying Surrepifungium species, viz. S. costulatum, S. ingridae, $S$. oliverioi and $S$. patamakanthini, are all considered generalists. They resemble mostly epitoniid species that live buried in the sediment underneath sea-anemones (Kokshoorn et al., 2007). Because they live hidden in the sand underneath their host corals it is difficult to observe their feeding behaviour in situ. Maybe the snails extend their proboscis towards the coral tissue while remaining protected in the substrate underneath as in the sea-anemone-associated Epitonium clathrus (Linnaeus, 1758) and E. clathratulum (Kanmacher, 1798) which may extend their proboscis to up to three times the shell-length towards the stem or the tentacles of the host (Perron, 1978: 65; Robertson, 1983: 4; den Hartog, 1987: 105; Gofas et al., 2011: 211).

If Epifungium and Surrepifungium species share a single host together (Table 1), the Epifungium is found on the coral itself while the Surrepifungium occurs on or in the substrate underneath. Epifungium snails are in general closer to their food, but they are also constantly within reach of the corals' nematocysts. They 
may be able to resist these nematocysts, which might explain why Epifungium species have more specialized host associations than Surrepifungium species. Likewise, commensal shrimp and fish species are also known to cohabitate single mushroom coral individuals, either living on different parts of the host or sharing similar places, especially in between tentacles of Heliofungia actiniformis (Hoeksema and Fransen, 2011; Bos, 2012).

Epifungium hartogi is the only Epifungium species that is associated with euphylliid corals. The snails are hidden deep inside the mouth cavity (the stomach) of their host (Gittenberger, 2003). They may only leave their shelter for spawning and are hard to detect. Other epitoniids may be hidden in similar habitats, although only few are known to live as endoparasites. Zahn (1980: 132) illustrates an epitoniid that hides in the cavity of a zoanthid belonging to the genus Sphenopus Steenstrup, 1856. This genus is unique among zoanthids because its species are free-living on sand or semiburied (Reimer et al., 2012). It is unclear whether its epitoniid associate is most closely related to burying wentletraps or epizoic species. Although many genera and species of Epitoniidae have been described (Gofas, 2012), the description of many is only based on the morphology of empty shells, while their host and mode of life remains unknown.

In general, sister species do not occur sympatrically and syntopically, but the sister taxa Epidendrium aureum and E. sordidum (for phylogenetic positions, see Gittenberger et al., 2006) are found in the same area on the same host species, Tubastraea sp., without any obvious niche differentiation as reflected by dissimilar life history strategies or radulas (Gittenberger and Gittenberger, 2005). However, E. sordidum is the only known epitoniid species with shells that are completely overgrown by other organisms, like hydroids, forams and vermetids (Fig. 4). They are therefore better camouflaged and more difficult to spot than the bright yellow E. aureum (Fig. 3). This kind of co-occurrence among sister taxa is not unique among gastropods, as recently shown for two ovulid snails (Lorenz and Melaun, 2011), and may either indicate sympatric or allopatric speciation. Possible mechanisms for sympatric speciation in gastropods may be related to differentiation in ecological traits (Krug, 2011). Other records of sister taxa with much overlap in distribution patterns concern several pairs of mushroom coral species in the Spermonde Archipelago (Hoeksema, 2012c).

Unlike endolithic molluscs (Hoeksema and Kleemann, 2002; Kleemann and Hoeksema, 2002; Mas- sin, 1989, 2000; Massin and Dupont, 2003; Gittenberger and Gittenberger, 2011; Owada and Hoeksema, 2011) ectoparasitic epitoniids do not inflict serious visible damage to their host corals, as for instance seen in infestations by flatworms (Hoeksema and Farenzena, 2012). The mucus layer secreted by mushroom corals may be a means to protect their soft tissue against damage and is believed to be nutritious for other animals (Krupp, 1982, 1984, 1985; Drollet et al., 1993). Mushroom corals are successful in regenerating and repairing their tissue (Chadwick and Loya, 1990; Kramarsky-Winter and Loya, 1996; ChadwickFurman et al., 2000). Owing to their fragmentation and their regenerative capacity and survival, some mushroom corals are even capable of forming large aggregations (Chadwick and Loya, 1990; Yamashiro and Nishihira, 1998; Gilmour, 2002, 2004; Hoeksema, 2004; Hoeksema and Gittenberger, 2010; Hoeksema and Waheed, 2011; Hoeksema and Yeemin, 2011). Hence, infestations by epitoniids may slightly harm mushroom corals and is not likely to have any lethal effect.

\section{Coral densities and depth ranges}

The infestation percentages by Epifungium ulu in the transects at 6, 9, 12 and $15 \mathrm{~m}$ depth on the reef slopes of W and E Kudingareng Keke, are independent of depth and negatively correlated with coral density (Fig. 19). Among the seven reefs that were studied in SW Sulawesi, only Lae-Lae had an exceptionally low infestation rate given the number of potential host corals. The mushroom corals on this reef belong to relatively few species that show high densities at shallow depths (Hoeksema, 2012a). The water around this nearshore reef is usually murky and the shallow sea floor contains much silt because of its close proximity to the mouth of the Jeneberang River (Fig. 2). Epitoniids are not exceptional among invertebrate benthic species by showing low species numbers and low densities on nearshore reefs on the Spermonde Shelf (Cleary et al., 2005; Becking et al., 2006; de Voogd et al., 2006; Hoeksema and Crowther, 2011). Similar patterns have been observed off Jakarta, where both molluscs and corals showed a decline in species richness on nearshore reefs as a result of terrigenous impact (van der Meij et al., 2009, 2010). Although mushroom corals are well capable of sediment-shedding (Bongaerts et al., 2012, Erftemeijer et al., 2012), their associated fauna may be less resistant to sedimentation (van der Meij and Hoeksema, 2013). 
The free-living fungiids on nearshore reefs in the Spermonde Archipelago occurred relatively more frequently on substrates with burrows than at the other localities (Fig. 21), which may also restrict their infestation rates (see Substrates). A negative correlation between coral density and number of infested individuals supports the hypothesis that epitoniid veliger larvae become evenly dispersed over coral reefs and depths. They can actually actively search for a suitable host by means of chemotaxis (Salo, 1977; Perron, 1978; Bell, 1985). This explains the relatively high infestation rates when few suitable fungiid hosts are present. Exceptions are reef sites that are dominated by mushroom coral species that appear to be immune to epitoniids, such as Heliofungia fralinae (see Hoeksema, 2004).

The use of chemotaxis may also explain how epitoniid species maintain their host specificity, although mushroom corals have been observed to form large and dense multi-species assemblages in various Indo-West Pacific localities, including the Red Sea (Pichon, 1974; Claereboudt, 1988; Goffredo and Chadwick-Furman, 2000; Latypov, 2007; Elahi, 2008; Hoeksema and Koh, 2009; Hoeksema and Matthews, 2011; Hoeksema, 2012a; Hoeksema et al., 2012b). Only in case of a potential shortage of preferred host corals it may be more advantageous for wentletrap species to switch from one host species to another, as also observed in corallivorous Drupella snails (Hoeksema et al., 2013).

Coral-associated epitoniids do not show a clear preference for a specific depth range (e.g. Fig. 19, Table 3). The only exception is an Epifungium twilae population in the Red Sea, where infestations were only recorded at $>29 \mathrm{~m}$ depth, even though potential hosts also occurred at shallower depths. This may be related to an unusually heavy rainfall in the year prior to the fieldwork, which formed several freshwater lakes in the desert, one of which drained towards the coast covering the research site with dirt and sand. Visibility remained only good at greater depths. Indirect evidence for epitoniids avoiding murky water was also found on Lae-Lae in the Spermonde Archipelago (see Coral densities and depth ranges), where infestation rates were much lower than on offshore reefs (Figs 18, 21).

\section{Substrates}

A significantly higher number of epitoniids was found on corals living on flat substrates than on sediment with burrows in them (Fig. 20). In the latter case they can more easily be reached by predators from below. This might also explain why in such cases most Epi- fungium ulu snails are observed on the substrate (Fig. 6 ) instead of on the coral's surface. Alternatively, when the underground is flat, the snails are found significantly more frequently attached to the coral itself. Most of the burrows found underneath mushroom corals (Figs 11, 13-14) were probably made by shrimps, like Alpheus frontalis (Fig. 15) and Axiopsis sp., and by goby shrimps and burrow-dwelling gobies. These shrimps and gobies may remove and eat epitoniids that lived above the burrowing. Surrepifungium snails burry into the sand for protection and are never found on the coral surface, in contrast to most Epifungium species, with the exception of E. hoeksemai (Table 3).

\section{Coral sizes and risk of host coral turnover}

Coral size matters in relation to infestations by epitoniids, which inhabit their hosts for only a limited time. For instance, the life history of Epifungium ulu (Bell, 1985), which includes eggs, a planktonic veliger stage, and the settling as a benthic snail has been observed to be completed within 36 days (Robertson, 1983, 1994; Bell, 1985; Collin, 2000; Gittenberger, 2003). However, variation in protoconch size and whorls number among epitoniids (Gittenberger and Gittenberger, 2005), suggests that the duration of the planktonic larval stage may be different in other species.

The presence of Epifungium ulu and E. twilae snails with their spawns, is clearly related to host size since [1] the snails are more frequently found underneath larger hosts (Figs 23-24), [2] larger snails are more often observed with larger hosts (Figs 25-26) and [3] individual snails are more frequently observed with spawns underneath the largest hosts (Table 4). These results can be explained by a combination of factors. Most importantly, since larger corals are usually older, they have been exposed to possible infestation for a longer period of time. A coral may be host for several generations of snails, although it is unknown whether these are successive generations, i.e. whether veligers settle on the same host as their parents.

Moreover, larger host corals are heavier than smaller ones and can be overturned less easily, thus preventing exposure of the snails to potential predators. The preference of epitoniids for larger hosts may also be related to the convex (domed) shape of large free-living mushroom corals (Hoeksema and Moka, 1989; Hoeksema, 1993c), leaving more living space for epitoniids in between the coral disc and the substrate. This is especially relevant for snails that do not bury into the sand, like most Epifungium species (Table 3), 
or species that have broad shells (height/width ratios 1.0-1.2), like E. pseudotwilae and E. twilae (Fig. 9). These wentletraps are found on fungiids that may become relatively large, like those belonging to Ctenactis, Herpolitha, Podabacia, Sandalolitha and Zoopilus (Table 1; Hoeksema 1989, 1991b).These polystomatous coral species have their mouths more or less evenly distributed over their upper surface, which allows them to become large (Hoeksema, 1991b). Because of their convex shape not all mouths are in direct contact with the substrate. Hence, large specimens may not right themselves easily and because of their high number of mouths, their upside-down position perhaps does not entirely prevent food intake, which may enable them to survive for long periods.

Epitoniids with more slender shells (height/width ratio $>2.0$ ) like Epifungium adgranulosa, E. adscabra, E. marki, E. nielsi (Fig. 7), E. lochi (Fig. 8) and E. pseudolochi, are associated either with small fungiids belonging to free-living Cycloseris species, Lithophyllon scabra, Pleuractis granulosa (Fig. 12), or oval Pleuractis species that can be slightly convex (Fig. 7).

Epitoniids are hardly ever found underneath fungiids that are turned upside-down or on top of their host in upright position, although many mushroom coral surveys were performed (e.g. Hoeksema, 1991a; 1993, 2012a, Hoeksema and Moka, 1989; Hoeksema and Koh, 2009; Hoeksema and Matthews, 2011; Waheed and Hoeksema, 2013). Wentletraps may become removed from their host within hours or days after the coral disc has been turned over (Fig. 27) and are either eaten by fishes (Figs 16-17) or removed by currents. They were also not found on neighbouring corals. The spawns may remain somewhat longer (Fig. 27) because they are attached to the host by several mucus threads instead of only one or two that hold the snails themselves (Gittenberger and Gittenberger, 2005). The righting ability differed significantly among various fungiid species (Table 5), as well as the relative frequency of specimens found in overturned position (Fig. 28). Hosts that do not easily overturn are less risky as hosts for wentletraps, but no preference for such species was found (Table 1).

Epifungium pseudotwilae and E. twilae are associated with relatively large mushroom coral species, e.g. those belonging to Ctenactis, Herpolitha, Sandalolitha and Zoopilus (Hoeksema, 1989, 1991b). Wrasses, damselfish and gobies are more frequently found underneath such large corals than small corals and may therefore be more threatening to E. pseudotwilae and E. twilae than to other Epifungium species. Their wide conical shells are noticeably broader than those of the other Epifungium species (Gittenberger and Gittenberger, 2005). Small fishes with narrow mouths that can reach the underside of the coral discs may not be able to grasp the shell of these species. The shells of both species are very similar in shape although they are not sister taxa (Gittenberger et al., 2006), which may reflect a convergent evolution as a result of a selective preference for longer shells by predatory fish. This hypothesis is supported by the exposure experiment in which damselfishes and wrasses only ate the slender specimens of Epifungium ulu, without attacking the relatively broad E. twilae shells.

\section{Conclusions and recommendations}

Twenty wentletrap snails (Epitoniidae) in the present study are known to be parasites of scleractinian corals: 17 species are associated with mushroom corals (Fungiidae), two Epidendrium species with dendrophylliid corals and one Epifungium species with two Plerogyra species (Euphylliidae) (Gittenberger and Gittenberger, 2005). Among the 17 snails associated with Fungiidae, 11 Epifungium spp. dwell on the host coral's under surface, four Surrepifungium spp. live buried in sediment underneath the host coral, and two Epitonium spp. have an unknown life style because they have only been found as empty shells in the proximity of mushroom corals. The species not associated with mushroom corals were found outside or inside in the host's polyps. Six Epifungium spp. on mushroom corals have been recorded with a single host species, like both Epitonium spp., while none of the Surrepifungium spp. are host-specific. Except for one occasion, no coral-associated wentletrap species showed a particular depth preference. Infestation rates were negatively correlated with coral densities, which indicates that epitoniid veliger larvae may actively look for preferential hosts. Holes underneath hosts appeared to have a restrictive influence on the occurrence of the associated snails. Malacovorous fishes consumed snails the moment their host corals were overturned, which suggests that the hosts normally provide the snails with protection against predators. Future evolutionary studies will deal with how snail-host associations relate to a molecular phylogeny reconstruction of the Epitoniidae (Gittenberger et al., in prep). Other research may focus on how numbers, sizes, the presence of spawns and sex of the snails varies among coral hosts and how these correspond with host size and the 
time of the year, which ideally could be carried out with the most common host and snail species, i.e. Epifungium ulu and E. twilae.

\section{Acknowledgements}

We are grateful to Prof. Dr. Edmund Gittenberger (Leiden) and Dr. David G. Reid (London) for critically discussing an early draft of the manuscript. Dr. Merijn Bos, Dr. Pat Colin, Ms. Lori Colin, Ms. Rachel Collin, Mr. Hans Ditlev, Dr. Mark Erdmann, Mr. Jeroen Goud, Mr. Victor de Grund, Dr. Bas Kokshoorn, Mr. Somnuk Patamakanthin, Mr. Somwang Patamakanthin, Mr. Niels Schrieken, and Dr. Nicole J. de Voogd are thanked for their help in providing information and material. Dr. Charles H.J.M. Fransen (Leiden) is thanked for the identification of the burrowing crustaceans. We are also grateful to Prof. Dr. Alfian Noor (Hasanuddin University, Makassar) for his support in Makassar. This research project was supported by WOTRO (grant nr. W 82-249) with additional funding by the SchureBeijerinck-Popping Fonds (KNAW), the Alida Buitendijkfonds (Leiden University and Naturalis Biodiversity Center), and the Jan Joost ter Pelkwijkfonds (Leiden University and Naturalis Biodiversity Center). The research in Indonesia was generously sponsored by the Indonesian Institute of Sciences (LIPI). We want to thank two anonymous reviewers for their constructive comments on the final manuscript.

\section{References}

Abe N. 1939. Migration and righting reaction of the coral Fungia actiniformis var. palawensis Döderlein. Palao Tropical Biological Station Studies 4: 671-694.

Abelson A, Loya Y. 1999. Interspecific aggression among stony corals in Eilat, Red Sea: a hierarchy of aggression ability and related parameters. Bulletin of Marine Science 65: 851-860.

Becking LE, Cleary FR, de Voogd NJ, Renema W, De Beer M, Van Soest RWM, Hoeksema BW. 2006. Betadiversity of tropical marine assemblages in the Spermonde Archipelago, Indonesia. Marine Ecology 27: 76-88.

Bell JL. 1985. Larval growth and metamorphosis of a prosobranch gastropod associated with a solitary coral. Proceedings of the $5^{\text {th }}$ International Coral Reef Congress 5: 159-164.

Benzoni F, Stefani F, Stolarski J, Pichon M, Mitta G, Galli P. 2007. Debating phylogenetic relationships of the scleractinian Psammocora: molecular and morphological evidences. Contributions to Zoology 76: 35-54.

Benzoni F, Arrigoni R, Stefani F, Reijnen BT, Montano S, Hoeksema BW. 2012. Phylogenetic position and taxonomy of Cycloseris explanulata and C. wellsi (Scleractinia: Fungiidae): Lost mushroom corals find their way home. Contributions to Zoology 81: 125-146.

Black R, Johnson MS. 1994. Growth rates in outbreak populations of the corallivorous gastropod Drupella cornus (Röding 1798) at Ningaloo Reef, Western Australia. Coral Reefs 13: 145-150.

Bleeker P. 1851. Bijdrage tot de kennis der ichthyologische fauna van de Banda-eilanden. Natuurkundig Tijdschrift voor Nederlandsch-Indië 2: 225-261.
Bonfitto A, Sabelli B. 2001. Epitonium (Asperiscala?) oliverioi, a new species of Epitoniidae (Gastropoda) from Madagascar. Journal of Molluscan Studies 67: 269-274.

Bongaerts P, Hoeksema BW, Hay KB, Hoegh-Guldberg O. 2012. Mushroom corals overcome live burial through pulsed inflation. Coral Reefs 31: 399.

Bos AR. 2012. Symbiotic fishes (Gobiidae and Labridae) of the mushroom coral Heliofungia actiniformis (Scleractinia; Fungiidae). Coral Reefs 31: 133.

Bouchet P, Warén A. 1986. Revision of the Northeast Atlantic bathyal and abyssal Aclididae, Eulimidae, Epitoniidae (Mollusca: Gastropoda). Bollettino Malacologico, Suppl. 2: 299-576.

Braga-Henriques A, Carreiro-Silva M, Porteiro FM, de Matos V, Sampaio Í, Ocaña O, Ávila SP. 2011. The association between a deep-sea gastropod Pedicularia sicula (Caenogastropoda: Pediculariidae) and its coral host Errina dabneyi (Hydrozoa: Stylasteridae) in the Azores. ICES Journal of Marine Science 68: 399-407.

Carpenter KE, Abrar M, Aeby G, et al. 2008. One-third of reefbuilding corals face elevated extinction risk from climate change and local impacts. Science 321: 560-563.

Carpenter PP. 1856. Monograph of the shells collected by T. Nuttall, Esq. On the Californian coast, in the years 1834-5. Proceedings of the Zoological Society of London. 1856: 209-229.

Castro A. 1988. Animal symbioses in coral reef communities: a review. Symbiosis 5: 161-184.

Chadwick NE. 1988. Competition and locomotion in a freeliving fungiid coral. Journal of Experimental Marine Biology and Ecology 133: 189-200.

Chadwick NE, Loya Y. 1990. Regeneration after experimental breakage in the solitary reef coral Fungia granulosa Klunzinger, 1879. Journal of Experimental Marine Biology and Ecology 142: 221-234.

Chadwick-Furman NE, Loya Y. 1992. Migration, habitat use, and competition among mobile corals (Scleractinia: Fungiidae) in the Gulf of Eilat, Red Sea. Marine Biology 114: 617-623.

Chadwick-Furman NE, Goffredo S, Loya Y. 2000. Growth and population dynamic model of the reef coral Fungia granulosa Klunzinger, 1879 at Eilat, northern Red Sea. Journal of Experimental Marine Biology and Ecology 249: 199-218.

Churchill CKC, Ó Foighil D, Strong EE, Gittenberger A. 2011. Females floated first in bubble-rafting snails. Current Biology 21: R802-803.

Claereboudt M. 1988. Spatial distribution of fungiid coral population on exposed and sheltered reef slopes in Papua New Guinea. Proceedings of the 6th International Coral. Reef Symposium, Townsville, Australia 2: 715-720.

Claremont M, Reid DG, Williams ST. 2011. Evolution of corallivory in the gastropod genus Drupella. Coral Reefs 30: 977-990.

Cleary DFR, Becking LE, de Voogd NJ, Renema W, De Beer M, Van Soest RWM, Hoeksema BW. 2005. Variation in the diversity and composition of benthic taxa as a function of distance offshore, depth and exposure in the Spermonde Archipelago, Indonesia. Estuarine Coastal and Shelf Science 65: 557-570.

Collin R. 2000. Development and anatomy of Nitidiscala tincta (Carpenter, 1865) (Gastropoda: Epitoniidae). Veliger 43: 302-312. 
Cumming RL. 1999. Predation on reef-building corals: multiscale variation in the density of three corallivorous gastropods, Drupella spp. Coral Reefs 18: 147-157.

Dana JD. 1846. United States Exploring Expedition during the years 1838-1842. Zoophytes 7. Lea and Blanchard, Philadelphia.

Ditlev H. 2003. New scleractinian corals (Cnidaria: Anthozoa) from Sabah, North Borneo. Description of one new genus and eight new species, with notes on their taxonomy and ecology. Zoologische Mededelingen, Leiden 77: 193219.

Döderlein L. 1901. Die Korallengattung Fungia. Zoologischer Anzeiger 24: 351-360.

Drollet JH, Glaziou P, Martin PMV. 1993. A study of mucus from the solitary coral Fungia fungites (Scleractinia: Fungiidae) in relation to photobiological UV adaptation. Marine Biology 115: 263-266.

Elahi R. 2008. Effects of aggregation and species identity on the growth and behavior of mushroom corals. Coral Reefs 27: 881-885.

Erftemeijer PLA, Riegl B, Hoeksema BW, Todd PA. 2012. Environmental impacts of dredging and other sediment disturbances on corals: a review. Marine Pollution Bulletin 64: $1737-1765$.

Esper EJC. 1797. Die Planzenthiere. Fortsetzungen 1 (1797): 1-230. Abbildungen I: Madrepora pls. 1-87. Raspischen Buchhandlung, Nurnberg.

Gilmour JP. 2002. Acute sedimentation causes size-specific mortality and asexual budding in the mushroom coral, Fungia fungites. Marine and Freshwater Research 53: 805-812.

Gilmour JP. 2004. Asexual budding in Fungiid corals. Coral Reefs 23: 595.

Gittenberger A. 2003. The wentletrap Epitonium hartogi spec. nov. (Gastropoda: Epitoniidae), associated with bubble coral species, Plerogyra spec. (Scleractinia: Euphylliidae), off Indonesia and Thailand. Zoologische Verhandelingen, Leiden 345: 139-150.

Gittenberger A, Gittenberger E. 2005. A hitherto unnoticed adaptive radiation: epitoniid species (Gastropoda: Epitoniidae) associated with corals (Scleractinia). Contributions to Zoology 74: 125-203.

Gittenberger A, Gittenberger E. 2011. Cryptic, adaptive radiation of parasitic snails: sibling species of Leptoconchus (Gastropoda: Coralliophilidae) in corals. Organisms, Diversity and Evolution 11: 21-41.

Gittenberger A, Goud J, Gittenberger E. 2000. Epitonium (Gastropoda: Epitoniidae) associated with mushroom corals (Scleractinia: Fungiidae) from Sulawesi, Indonesia, with the description of four new species. The Nautilus 114: $1-13$.

Gittenberger A, Kokshoorn E, Gittenberger E. 2006. A molecular phylogeny of Epitoniidae (Mollusca: Gastropoda), focusing on the species associated with corals. Pp. 207-213 in: Gittenberger A: The evolutionary history of parasitic gastropods and their coral hosts in the Indo-Pacific. $\mathrm{PhD}$ thesis, Leiden University.

Gittenberger A, Reijnen BT, Hoeksema BW. 2011. A molecularly based phylogeny reconstruction of mushroom corals (Scleractinia: Fungiidae) with taxonomic consequences and evolutionary implications for life history traits. Contributions to Zoology 80: 107-132.
Gofas S. 2012. Epitoniidae. Accessed through: World Register of Marine Species at http://www.marinespecies.org/aphia. php? $\mathrm{p}=$ taxdetails \&id=132 on 2012-11-11

Gofas S, Moreno D, Salas C. 2011. Moluscos marinos de Andalucía: una guía para su identificación. Vol. I. Servicio de Publicaciones e Intercambio Científico, Universidad de Málaga.

Goffredo S, Chadwick-Furman NE. 2000. Abundance and distribution of mushroom corals (Scleractinia: Fungiidae) on a coral reef at Eilat, northern Red Sea. Bulletin of Marine Science 66: 241-245.

Goreau TF, Goreau NI, Neumann Y. 1968. Fungiacava eilatensis n. gen., n. sp. (Bivalvia, Mytitidae), a boring bivalve commensal in reef corals. American Zoologist 8: 799.

Goud J, Hoeksema BW. 2001. Pedicularia vanderlandi spec. nov. (Gastropoda: Ovulidae), a symbiotic snail on the hydrocoral Distichopora vervoorti Cairns \& Hoeksema, 1998 (Hydrozoa: Stylasteridae) from Bali, Indonesia. Zoologische Verhandelingen, Leiden 334: 77-97.

Hadfield MG. 1976. Molluscs associated with living tropical corals. Micronesica 12: 133-148.

Hartog JC den. 1987. Observations of the wentletrap Epitonium clathratulum (Kanmacher, 1797) (Prosobranchia, Epitoniidae) and the sea anemone Bunodosoma biscayensis (Fischer, 1874) (Actiniaria, Actiniidae). Basteria 51: 95-108.

Hoeksema BW. 1988. Mobility of free living fungiid corals (Scleractinia), a dispersion mechanism and survival strategy in dynamic reef habitats. Proceedings 6th International Coral Reef Symposium 2: 715-720.

Hoeksema BW. 1989. Taxonomy, phylogeny and biogeography of mushroom corals (Scleractinia: Fungiidae). Zoologische Verhandelingen, Leiden 254: 1-295.

Hoeksema BW. 1990. Systematics and ecology of mushroom corals (Scleractinia: Fungiidae). PhD Thesis, Leiden University.

Hoeksema BW. 1991a. Control of bleaching in mushroom coral populations (Scleractinia: Fungiidae) in the Java Sea: stress tolerance and interference by life history strategy. Marine Ecology Progress Series 74: 225-237.

Hoeksema BW. 1991b. Evolution of body size in mushroom corals (Scleractinia: Fungiidae) and its ecomorphological consequences. Netherlands Journal of Zoology 41: 122-139.

Hoeksema BW. 1993a. Mushroom corals (Scleractinia: Fungiidae) of Madang Lagoon, northern Papua New Guinea: an annotated checklist with the description of Cantharellus jebbi spec. nov. Zoologische Mededelingen, Leiden 67: 1-19.

Hoeksema BW. 1993b. Historical biogeography of Fungia (Pleuractis) spp. (Scleractinia: Fungiidae), including a new species from the Seychelles. Zoologische Mededelingen, Leiden 67: 639-654.

Hoeksema BW. 1993c. Phenotypic corallum variability in Recent mobile reef corals. Courier Forschungsinstitut Senckenberg 164: 263-272.

Hoeksema BW. 2004. Impact of budding on free-living corals at East Kalimantan, Indonesia. Coral Reefs 23: 492.

Hoeksema BW. 2007. Delineation of the Indo-Malayan centre of maximum marine biodiversity: The coral triangle. Pp. 117-178 in: Renema W., ed., Biogeography, time and place: distributions, barriers and islands. Springer, Dordrecht.

Hoeksema BW. 2009. Attached mushroom corals (Scleractinia: Fungiidae) in sediment-stressed reef conditions at Singa- 
pore, including a new species and a new record. Raffles Bulletin of Zoology Suppl. 22: 81-90.

Hoeksema BW. 2012a. Distribution patterns of mushroom corals (Scleractinia: Fungiidae) across the Spermonde Shelf, South Sulawesi. Raffles Bulletin of Zoology 60: 183-212.

Hoeksema BW. 2012b. Mushroom corals (Scleractinia: Fungiidae) of Espiritu Santo (Vanuatu, West Pacific) with the description of a new species. Zoosystema 34: 429-443.

Hoeksema BW. 2012c. Evolutionary trends in onshore-offshore distribution patterns of mushroom coral species (Scleractinia: Fungiidae). Contributions to Zoology 81: 199-221.

Hoeksema BW, Crowther AL. 2011. Masquerade, mimicry and crypsis of the polymorphic sea anemone Phyllodiscus semoni and its aggregations in South Sulawesi. Contributions to Zoology 80: 251-268.

Hoeksema BW, Dai CF. 1991. Scleractinia of Taiwan. II Family Fungiidae (with the description of a new species). Bulletin Zoological Institute, Academia Sinica, Taipei 30: 201-226.

Hoeksema BW, Farenzena ZT. 2012. Tissue loss in corals infested by acoelomorph flatworms (Waminoa sp.). Coral Reefs 31: 869 .

Hoeksema BW, Fransen CHJM. 2011. Space partitioning by symbiotic shrimp species cohabitating in the mushroom coral Heliofungia actiniformis at Semporna, eastern Sabah. Coral Reefs 30: 519.

Hoeksema BW, Gittenberger A. 2008. Records of some marine parasitic molluscs from Nha Trang, Vietnam. Basteria 72: $129-133$.

Hoeksema BW, Gittenberger A. 2010. High densities of mushroom coral fragments at West Halmahera, Indonesia. Coral Reefs 29: 691.

Hoeksema BW, Kleemann K. 2002. New records of Fungiacava eilatensis Goreau et al., 1968 (Bivalvia: Mytilidae) boring in Indonesian mushroom corals (Scleractinia: Fungiidae). Basteria 66: 25-30.

Hoeksema BW, Koh EGL. 2009. Depauperation of the mushroom coral fauna (Fungiidae) of Singapore (1860s-2006) in changing reef conditions. Raffles Bulletin of Zoology Suppl. 22: 91-101.

Hoeksema BW, Matthews JL. 2011. Contrasting bleaching patterns in mushroom coral assemblages at Koh Tao, Gulf of Thailand. Coral Reefs 30: 95.

Hoeksema, BW, Moka W. 1989. Species assemblages and phenotypes of mushroom corals (Fungiidae) related to coral reef habitats in the Flores Sea. Netherlands Journal of Sea Research 23: 149-160.

Hoeksema BW, de Voogd NJ. 2012. On the run: free-living mushroom corals avoiding interaction with sponges. Coral Reefs 31: 455-459.

Hoeksema BW, Waheed Z. 2011. Initial phase of autotomy in fragmenting Cycloseris corals at Semporna, eastern Sabah, Malaysia. Coral Reefs 30: 1087.

Hoeksema BW, Yeemin T. 2011. Late detachment conceals serial budding by the free-living coral Fungia fungites in the Inner Gulf of Thailand. Coral Reefs 30: 975.

Hoeksema BW, van der Meij SET, Fransen CHJM. 2012a. The mushroom coral as a habitat. Journal of the Marine Biological Association of the United Kingdom 92: 647-633.

Hoeksema BW, Matthews JL, Yeemin T. 2012b. The 2010 coral bleaching event and its impact on the mushroom coral fauna of Koh Tao, Western Gulf of Thailand. Phuket Marine Biological Center Research Bulletin 71: 71-81.

Hoeksema BW, Scott C, True JD. 2013. Dietary shift in corallivorous Drupella snails following a major bleaching event at Koh Tao, Gulf of Thailand. Coral Reefs doi: 10.1007/ s00338-012-1005-X.

Hubbard JAEB. 1972. Diaseris distorta, an "acrobatic" coral. Nature 236: 457-459.

Johnson MS, Cumming RL. 1995. Genetic distinctness of three widespread and morphologically variable species of Drupella (Gastropoda, Muricidae). Coral Reefs 14: 71-78.

Jokiel PL, Cowdin HP. 1976. Hydromechanical adaptation in the solitary free-living coral Fungia scuturia. Nature 262: 212-213.

Kanmacher F. 1798. Second edition of Adams J, Essays on the microscope : containing a practical description of the most improved microscopes; a general history of insects, their transformations, peculiar habits, and oeconomy : an account of the various species, and singular properties, of the hydrae and vorticellae: a description of three hundred and eightythree animalcula : with a concise catalogue of interesting objects: a view of the organization of timber, and the configuration of salts, when under the microscope. Dillon and Keating, London.

Kiener LC. 1839. Genre Scalaire. Pp. 1-22, Pls 1-7 in: Species general et iconographie des coquilles vivantes comprenant la collection du Muséum d'histoire naturelle de Paris : la collection Lamarck, celle du prince Masséna (appartenant maintenant a M.B. Delessert) et les découvertes récentes des voyageurs. Rousseau and Baillière, Paris.

Kleemann K, Hoeksema BW. 2002. Lithophaga (Bivalvia: Mytilidae), including a new species, boring in mushroom corals (Scleractinia: Fungiidae) at South Sulawesi, Indonesia. Basteria 66: 11-24.

Klunzinger CB. 1879. Die Korallenthiere des Rothen Meeres 3. Gutmann, Berlin.

Kokshoorn B, Goud J, Gittenberger E, Gittenberger A. 2007. Epitoniid parasites (Gastropoda, Prosobranchia, Epitoniidae) and their host sea anemones (Cnidaria, Actiniaria, Ceriantharia) in the Spermonde archipelago, Sulawesi, Indonesia. Basteria 71: 33-56.

Kramarsky-Winter E, Loya Y. 1996. Regeneration versus budding in fungiid corals: a trade-off. Marine Ecology Progress Series 134: 179-185.

Krug PJ. 2011, Patterns of speciation in marine gastropods: A review of the phylogenetic evidence for localized radiations in the sea. American Malacological Bulletin 29: 169186.

Krupp DA. 1982. The composition of the mucus from the mushroom coral Fungia scutaria. Proceedings 4th International Coral Reef Symposium, Manila 2: 9-73.

Krupp DA. 1984. Mucus production by corals exposed during an extreme low tide. Pacific Science 38: 1-11.

Krupp DA. 1985. An immunochemical study of the mucus from the solitary coral Fungia scutaria (Scleractinia, Fungiidae). Bulletin of Marine Science 35: 163-175.

Lamarck JBPA de M de. 1801. Systeme des animaux sans vertebres. Deterville, Paris.

Latypov YY. 2007. Free-living scleractinian corals on reefs of the Seychelles Islands. Russian Journal of Marine Biology 33: 222-226. 
Linneaus C. 1758. Systema Naturae. Regnum Animale. Laurentii Salvii, Holmiae, Stockholm.

Lorenz F, Melaun, C. 2011. A new species of Simnia from England (Caenogastropoda: Ovulidae). Molluscan Research 31: 167-175.

Massin C. 1989. Boring Coralliophilidae (Mollusca, Gastropoda): coral host relationship. Proceedings of the 6th International Coral Reef Symposium 3: 177-184.

Massin C. 2000. Ecology of the Leptoconchus spp. (Gastropoda, Coralliophilidae) infesting Fungiidae (Anthozoa, Madreporaria). Bulletin de l'Institut Royal des Sciences Naturelles de Belgique, Biologie 70: 235-252.

Massin C, Dupont S. 2003. Study on the Leptoconchus (Gastropoda, Coralliophilidae) infesting Fungiidae (Anthozoa: Scleractinia): 1. Presence of nine Operational taxonomic units (OTUs) based on anatomical and ecological characters. Belgian Journal of Zoology 133: 123-128.

Meij SET van der, Hoeksema BW. 2013. Distribution of gall crabs inhabiting mushroom corals on Semporna reefs, Malaysia. Marine Biodiversity doi: 10.1007/s12526-012$\underline{0135-2}$

Meij SET van der, Moolenbeek RG, Hoeksema BW. 2009. Decline of the Jakarta Bay molluscan fauna linked to human impact. Marine Pollution Bulletin 59: 101-107.

Meij SET van der, Suharsono, Hoeksema BW. 2010. Long-term changes in coral assemblages under natural and anthropogenic stress in Jakarta Bay (1920-2005). Marine Pollution Bulletin 60: 1442-1454.

Milne Edwards H. 1837. Histoire naturelle des Crustacés, comprenant l'anatomie, la physiologie et la classification de ces animaux, II. Librairie de Roret, Paris.

Morton B, Blackmore G. 2009. Seasonal variations in the density of and corallivory by Drupella rugosa and Cronia margariticola (Caenogastropoda: Muricidae) from the coastal waters of Hong Kong: 'plagues' or 'aggregations'. Journal of the Marine Biological Association of the United Kingdom 89: 147-159.

Nemenzo F. 1955. Systematic studies on Philippine shallowwater scleractinians I. Suborder Fungiida. Natural and Applied Science Bulletin 15: 3-84, pls. 1-14.

Owada M, Hoeksema BW. 2011. Molecular phylogeny and shell microstructure of Fungiacava eilatensis Goreau et al., 1968, boring into mushroom corals (Scleractinia: Fungiidae), in relation to other mussels (Bivalvia: Mytilidae). Contributions to Zoology 80: 169-178.

Pallas PS. 1766. Elenchus Zoophytorum. Van Cleef, HagaeComitum.

Perron F. 1978. The habitat and feeding behavior of the wentletrap Epitonium greenlandicum. Malacologia 17: 63-72.

Pichon M. 1974. Free living scleractinian coral communities in the coral reefs of Madagascar. Proceedings of the 2nd International Coral Reef Symposium, Brisbane 2: 173-181.

Pilsbry HA. 1921. Marine mollusks of Hawaii. Proceedings of the Academy of Naturals Sciences of Philadelphia 72: 360382.

Plusquellec Y, Webb G, Hoeksema BW. 1999. Automobility in Tabulata, Rugosa, and Extant scleractinian analogues: stratigraphic and paleogeographic distribution of Paleozoic mobile corals. Journal of Palaeontology 73: 985-1001.

Quelch JJ. 1886. Report on the reef-corals collected by H.M.S. Challenger during the years 1873-76. Report on the Scien- tific Results of the Voyage of H.M.S. Challenger, Zoology 16 (3): 1-203, pls. 1-12.

Quoy JRC, Gaimard P. 1825, Description des Poissons. Chapter IX. In: Freycinet L de, Voyage autour du Monde..exécuté sur les corvettes de L. M. "L'Uranie" et "La Physicienne," pendant les années 1817, 1818, 1819 et 1820. Paris. Description des Poissons. Chapter IX. In: Freycinet, L. de, Voyage autour du Monde, pp. 329-616, Atlas pls. 43-65.

Quoy JRC, Gaimard P. 1833. Voyage de Découvertes de l'Astrolabe Exécuté par Ordre du Roi, Pendant les Années 18261827-1828-1829, sous le Commandement de M.J. Dumont D'Urville. J. Tastu, Paris.

Rehberg H. 1892. Neue und wenig bekannte Korallen. Abhandlungen Naturwissenschaftligen Verein Hamburg 12: 1-50, pls. 1-4.

Reimer JD, Lin M, Fujii T, Lane DJW, Hoeksema BW. 2012. The phylogenetic position of the solitary zoanthid genus Sphenopus (Cnidaria: Hexacorallia). Contributions to Zoology 81: 43-54.

Reijnen BT, Hoeksema BW, Gittenberger E. 2010. Host specificity and phylogenetic relationships among Atlantic Ovulidae (Mollusca: Gastropoda). Contributions to Zoology 79: 69-78.

Robertson R. 1963. Wentletraps (Epitoniidae) feeding on sea anemones and corals. Proceedings of the Malacological Society of London 35: 51-63.

Robertson R. 1966. Coelenterate-associated prosobranch gastropods. American Malacological Union Annual Reports 1965: 6-8.

Robertson R. 1970. Review of the predators and parasites of stony corals with special reference to symbiotic prosobranch gastropods. Pacific Science 24: 43-54.

Robertson R. 1981. Epitonium millecostatum and Coralliophila clathrata: Two prosobranch gastropods symbiothic with Indo-Pacific Palythoa (Coelenterata: Zoanthidae). Pacific Science 34: 1-17.

Robertson R. 1983. Observations on the life history of the wentletrap Epitonium albidum in the West Indies. American Malacological Union Bulletin 1: 1-12.

Robertson R. 1994. Wentletrap egg capsules and veligers: what they are and how to see and study them. American Conchologist 22: 5-6.

Rüppell E. 1834. Description of a new genus of pectinibranchiated gasteropodous Mollusca (Leptoconchus). Proceedings of the Zoological Society of London 2: 105-106.

Salo S. 1977. Observations on feeding, chemoreception and toxins in two species of Epitonium. Veliger 20: 168-172.

Schiaparelli S, Barucca M, Olmo E, Boyer M, Canapa A. 2005. Phylogenetic relationships within Ovulidae (Gastropoda: Cypraeoidea) based on molecular data from the 16SrRNA gene. Marine Biology 147: 411-420.

Schimek RL. 1986. A diet that stings; sea anemones as food for snails. Shells and Sea Life 18(11): 173-175.

Sheppard CRC. 1979. Interspecific aggression between reef corals with reference to their distribution. Marine Ecology Progress Series 1: 237-247.

Steenstrup JJS. 1856. Sphenopus marsupialis (Gmelin). Saerskilt Aftryk. Af det Kongelige danske Videnskabernes Selkabs Forhandlinger.

Stella JS, Jones GP, Pratchett MS. 2010. Variation in the structure of epifaunal invertebrate assemblages among coral hosts. Coral Reefs 29: 957- 973. 
Stella JS, Pratchett MS, Hutchings PA, Jones GP. 2011. Coralassociated invertebrates: diversity, ecological importance and vulnerability to disturbance. Oceanography and Marine Biology: An Annual Review 49: 43-104.

Stutchbury S. 1833. An account of the mode of growth of young corals of the genus Fungia. Transactions of the Linnean Society of London 16: 493-497.

Thomason JC, Brown BE. 1986. The cnidom: an index of aggressive proficiency in scleractinian corals. Coral Reefs 5: 93-101.

Turner SJ. 1994. The biology and population outbreaks of the corallivorous gastropod Drupella on Indo-Pacific reefs. Oceanography and Marine Biology: An Annual Review 32: 461-530.

Verrill AE. 1864. List of the polyps and corals sent by the Museum of Comparative Zoology to other institutions in exchange, with annotations. Bulletin of the Museum of Comparative Zoology 1: 29-60.

Voogd NJ de, Cleary DFR, Hoeksema BW, Noor A, Van Soest RWM. 2006. Sponge betadiversity in the Spermonde Archi- pelago, Indonesia. Marine Ecology Progress Series 309: 131-142.

Waheed Z, Hoeksema BW. 2013. A tale of two winds: species richness patterns of reef corals around the Semporna peninsula, Malaysia. Marine Biodiversity. doi: 10.1007/s12526012-0130-7

Yamashiro H, Nishihira M. 1995. Phototaxis in Fungiidae corals (Scleractinia). Marine Biology 124: 461-465.

Yamashiro H, Nishihira M. 1998. Experimental study of growth and asexual reproduction in Diaseris distorta (Michelin, 1843), a free-living fungiid coral. Journal of Experimental Marine Biology and Ecology 225: 253-267.

Zahn LP. 1980. Living together in the sea. TFH Publications, Neptune.

Received: 21 May 2012

Revised and accepted: 17 December 2012

Published online: 29 January 2013

Editor: R.W.M. van Soest 